\title{
The Complement Receptor C5aR Controls Acute Inflammation and Astrogliosis following Spinal Cord Injury
}

\author{
Faith H. Brennan, ${ }^{1}$ Richard Gordon, ${ }^{1}$ Hong W. Lao, ${ }^{1}$ Patrick J. Biggins, ${ }^{1}$ Stephen M. Taylor, ${ }^{1}$ Robin J.M. Franklin, ${ }^{2}$ \\ Trent M. Woodruff, ${ }^{1}$ and Marc J. Ruitenberg ${ }^{1,3,4}$ \\ ${ }^{1}$ School of Biomedical Sciences, University of Queensland, Brisbane, 4072, Australia, ${ }^{2}$ Wellcome Trust-Medical Research Council, Cambridge Stem Cell \\ Institute \& Department of Clinical Neurosciences, University of Cambridge, Cambridge, CB2 0AH, United Kingdom, ${ }^{3}$ Queensland Brain Institute, \\ University of Queensland, Brisbane, 4072, Australia, and ${ }^{4}$ Trauma, Critical Care and Recovery, Brisbane Diamantina Health Partners, Brisbane, 4072, \\ Australia
}

This study investigated the role of the complement activation fragment C5a in secondary pathology following contusive spinal cord injury (SCI). $\mathrm{C5ar}^{-1-}$ mice, which lack the signaling receptor for $\mathrm{C} 5 \mathrm{a}$, displayed signs of improved locomotor recovery and reduced inflammation during the first week of SCI compared with wild-type mice. Intriguingly, the early signs of improved recovery in $\mathrm{C}_{\mathrm{aar}}{ }^{-1-}$ mice deteriorated from day 14 onward, with absence of $\mathrm{C} 5 \mathrm{aR}$ ultimately leading to poorer functional outcomes, larger lesion volumes, reduced myelin content, and more widespread inflammation at $35 \mathrm{~d}$ SCI. Pharmacological blockade of C5aR with a selective antagonist (C5aR-A) during the first $7 \mathrm{~d}$ after SCI improved recovery compared with vehicle-treated mice, and this phenotype was sustained up to $35 \mathrm{~d}$ after injury. Consistent with observations made in $\mathrm{C} \mathrm{ar}^{-1-}$ mice, these improvements were, however, lost if C5aR-A administration was continued into the more chronic phase of SCI. Signaling through the C5a-C5aR axis thus appears injurious in the acute period but serves a protective and/or reparative role in the post-acute phase of SCI. Further experiments in bone marrow chimeric mice suggested that the dual and opposing roles of $\mathrm{C} 5 \mathrm{aR}$ on SCI outcomes primarily relate to its expression on CNS-resident cells and not infiltrating leukocytes. Additional in vivo and in vitro studies provided direct evidence that $\mathrm{C} 5 \mathrm{aR}$ signaling is required during the postacute phase for astrocyte hyperplasia, hypertrophy, and glial scar formation. Collectively, these findings highlight the complexity of the inflammatory response to SCI and emphasize the importance of optimizing the timing of therapeutic interventions.

Key words: anaphylatoxin; CNS trauma; demyelinating pathology; macrophage; oligodendrocyte precursor cell; secondary degeneration

\section{Introduction}

The complex inflammatory response to traumatic spinal cord injury (SCI) contains elements that are known to be required for successful wound healing in other tissues; in context of CNS injury, these can, however, also cause additional damage to spared neural tissue (Donnelly and Popovich, 2008). A more in-depth understanding of these seemingly opposing roles of inflammation is therefore required, such that new and effective immune-modulatory therapies can be developed to improve

\footnotetext{
Received Dec. 17, 2014; revised Feb. 26, 2015; accepted March 17, 2015.

Author contributions: F.H.B., S.M.T., R.J.M.F., T.M.W., and M.J.R. designed research; F.H.B., R.G., H.W.L., P.J.B., and M.J.R. performed research; F.H.B., R.G., H.W.L., and M.J.R. analyzed data; F.H.B. and M.J.R. wrote the paper.

Work in the laboratory of M.J.R. was supported by SpinalCure Australia (Career Development Fellowship to M.J.R.), the University of Queensland, and the National Health and Medical Research Council of Australia (Project Grant 1060538). T.M.W. was supported by Australian Research Council Future Fellowship FT110100332. T.M.W. and S.M.T. were also supported by the National Health and Medical Research Council of Australia (Project Grant 1004455). F.H.B. and P.J.B. were each supported by an Australian Postgraduate Award (University of Queensland). We thank Dr. Rick Wetsel for originally providing the $\mathrm{C}^{\mathrm{aar}}{ }^{-/-}$mice; Dr. Linda Blomster for assistance with the generation of bone marrow chimeric mice; Geoff Osborne and Virginia Nink (Queensland Brain Institute, University of Queensland) for assistance with flow cytometry; and the technical staff of the University of Queensland Biological Resources for assistance with animal husbandry.

The authors declare no competing financial interests.

Correspondence should be addressed to Dr. Marc J. Ruitenberg, School of Biomedical Sciences, University of Queensland, Brisbane, QLD 4072, Australia. E-mail: m.ruitenberg@uq.edu.au.

DOI:10.1523/JNEUROSCI.5218-14.2015

Copyright $\odot 2015$ the authors $\quad 0270-6474 / 15 / 356517-15 \$ 15.00 / 0$
}

recovery from SCI, and potentially other acquired CNS injuries. The innate immune complement system, composed of $>30$ soluble and membrane-bound proteins, receptors, and regulators, is a major component of trauma-induced neuroinflammation (Anderson et al., 2004; Brennan et al., 2012). Previous studies have already shown that SCI outcomes can be improved through genetic deletion or pharmacological blockade of complement opsonins (Ankeny et al., 2009), the lytic membrane attack complex (Li et al., 2009), as well as more general interference with the main (i.e., classical, lectin, and alternative) pathways for complement system activation (Reynolds et al., 2004; Qiao et al., 2006, 2010; Guo et al., 2010). The role of the C5a activation fragment in the immune response to SCI remains, however, uncertain.

C5a is a 74 amino acid peptide that is generated by the proteolysis of complement protein C5. It is known to be a potent chemoattractant molecule through interaction with its G-protein-coupled receptor C5aR (CD88) (Ward and Newman, 1969), which is present on most leukocytes (Chenoweth and Hugli, 1978; Chenoweth et al., 1982). In the CNS, C5aR expression has been reported on neurons (Stahel et al., 1997; O'Barr et al., 2001; Bénard et al., 2004; Woodruff et al., 2006; Humayun et al., 2009), astrocytes (Gasque et al., 1995; Lacy et al., 1995; Woodruff et al., 2008), microglia (Lacy et al., 1995; Griffin et al., 2007), 
oligodendrocytes (Nataf et al., 2001), and neural progenitor cells (Farkas et al., 1999; Rahpeymai et al., 2006).

Previous in vivo studies have shown that parenchymal C5a/ C5aR expression is increased in models of traumatic brain injury (Stahel et al., 1997), intracerebral hemorrhage (Xi et al., 2001), and ischemic injury (Van Beek et al., 2000; Pavlovski et al., 2012), as well as in the plasma of human patients with stroke (Mocco et al., 2006) and subarachnoid hemorrhage (Mack et al., 2007). More importantly, acute inhibition of the C5a-C5aR axis improves outcomes from experimental ischemic stroke (Kim et al., 2008; Pavlovski et al., 2012) and intracerebral hemorrhage (Garrett et al., 2009). Intriguingly, although acute C5aR blockade is thought to attenuate inflammation, delayed antagonism of this receptor, starting 2 weeks after injury, led to significantly exacerbated SCI outcomes (Beck et al., 2010). These findings suggest a novel neuroprotective/reparative role for $\mathrm{C} 5 \mathrm{aR}$ signaling in the postacute phase of neurotrauma, although the mechanisms behind these observations are poorly understood. In the present

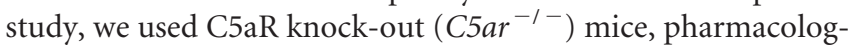
ical targeting of $\mathrm{C} 5 \mathrm{aR}$, bone marrow chimeras, and in vitro studies to better understand the role of the C5a-C5aR axis in SCI.

\section{Materials and Methods}

Animals. Adult female age- and weight-matched C57BL/6J (wild-type [WT]; $n=147)$, C5ar $^{-1-}(n=62)$ (Hollmann et al., 2008), and Macgreen (Csflr-EGFP, $n=24$ ) (Sasmono et al., 2003) mice were used in this study. $\mathrm{C}_{\mathrm{arr}}{ }^{-1-}$ and Macgreen mice had been backcrossed for $>10$ generations onto the C57BL/6J genetic background. All animals were obtained from local breeding colonies at the University of Queensland's Biological Resources facility. Mice were maintained in individually ventilated cages under standard conditions on a $12 \mathrm{~h}$ light-dark cycle with ad libitum access to food and water. All experimental procedures were approved by the University of Queensland's Animal Ethics Committee and conducted in accordance with the relevant National Health and Medical Research Council of Australia policies.

SCI. Mice were anesthetized with a mixture of tiletamine/zolezepam (50 mg/kg; Virbac) and xylazine (20 mg/kg; Troy Laboratories), after which they underwent contusive SCI. In brief, this involved identification of the ninth thoracic $(\mathrm{T})$ vertebra based on anatomical landmarks (Harrison et al., 2013), followed by dorsal laminectomy of T9 as described previously (Scheff et al., 2003; Blomster et al., 2013a). Next, a severe ( $\sim 70$ kdyne) contusion injury was inflicted on the spinal cord using the Infinite Horizon impactor device (Precision Systems and Instrumentation). Following this, muscle and skin were closed separately using 6-0 polyglactin dissolvable sutures (Ethicon) and Michel wound clips (Kent Scientific), respectively. Investigators performing surgery were blinded to the genotype and/or treatment condition of the animals. Postoperatively, animals received a single injection of buprenorphine $(0.5 \mathrm{mg} / \mathrm{kg}$ s.c. $)$ in Hartmann's sodium lactate solution for analgesia and were administered antibiotics ( $1.0 \mathrm{mg} / \mathrm{kg}$ gentamicin s.c.) for the first $5 \mathrm{~d}$ after injury. Bladders were manually voided twice daily for the duration of the experiments.

C5a ELISA. To determine the time course of C5a generation following SCI, WT mice were subjected to either SCI or sham surgery and then killed with sodium pentobarbitone $(100 \mathrm{mg} / \mathrm{kg}$ i.p., Virbac) at $30 \mathrm{~min}$, $2 \mathrm{~h}, 6 \mathrm{~h}, 12 \mathrm{~h}, 1 \mathrm{~d}, 4 \mathrm{~d}, 7 \mathrm{~d}$, or $35 \mathrm{~d}$ after injury ( $n=4$ or 5 per time point). An additional 4 unoperated (i.e., naive) mice were used to assess C5a levels under normal homeostatic conditions (time point 0 ).

At the appropriate time point, $0.5 \mathrm{ml}$ of volume of blood was collected directly from the heart via cardiac puncture using a syringe containing 30 $\mu \mathrm{l}$ of $4 \mathrm{~mm}$ EDTA. Blood samples were mixed immediately with $10 \mu \mathrm{l}$ of the complement inhibitor FUT175 (5 mg/ml; BD Biosciences) and stored on ice. Samples were centrifuged at $13,000 \times \mathrm{g}$ for $10 \mathrm{~min}$ at $4^{\circ} \mathrm{C}$, after which the supernatant was collected, aliquoted, and stored at $-80^{\circ} \mathrm{C}$. The T11-T13 spinal cord segment was also dissected immediately after the cardiac bleed, snap frozen in liquid nitrogen, and then stored at $-80^{\circ} \mathrm{C}$. Spinal cord samples were ground to a fine powder using a mortar and pestle on dry ice, then dissolved in $200 \mu$ l of NP-40 lysis buffer (Invitrogen) containing $1 \mathrm{~mm}$ PMSF (reconstituted in DMSO) (SigmaAldrich), 92.6 $\mu \mathrm{M}$ FUT175 (BD Biosciences), and $5 \mu$ l of protease inhibitor mixture (Sigma-Aldrich). Samples were vortexed for $1 \mathrm{~min}$, incubated on ice for $1 \mathrm{~h}$, and then centrifuged at 13,000 $\times \mathrm{g}$ for $30 \mathrm{~min}$ at $4^{\circ} \mathrm{C}$. Supernatants were collected, aliquoted, and stored at $-80^{\circ} \mathrm{C}$. An ELISA (R\&D Systems, \#DY2150) was then used to determine the concentration of $\mathrm{C} 5 \mathrm{a}$ in blood plasma and spinal cord samples according to the manufacturer's instructions; all samples were detected within the linear aspect of the standard curve. For spinal cord samples, the measured concentration of $\mathrm{C} 5 \mathrm{a}$ was always normalized to the protein concentration of the sample, which was measured by a BCA protein assay (Thermo Scientific, \#23227) according to the manufacturer's instructions.

Tissue processing for MRI and histology. Mice were anesthetized with sodium pentobarbitone (100 mg/kg i.p., Virbac) at their specified endpoints (see Results). Mice were then transcardially perfused with $20 \mathrm{ml}$ of saline $(0.9 \% \mathrm{NaCl})$ containing $10 \mathrm{IU} / \mathrm{ml}$ heparin (Pfizer) and $2 \%$ $\mathrm{NaNO}_{3}$, followed by $30 \mathrm{ml}$ of phosphate-buffered Zamboni's fixative ( $2 \%$ picric acid, $2 \%$ formaldehyde, $\mathrm{pH} 7.2-7.4$ ). The perfused vertebral column was then dissected out and postfixed overnight at $4^{\circ} \mathrm{C}$. Spinal cord specimens were then imaged where applicable (see MRI), dissected out from the vertebral column, and cryoprotected via subsequent overnight incubations in $10 \%$ and $30 \%$ sucrose solutions. Next, the lesion segment of the spinal cord was embedded in Optimal Cooling Temperature (OCT) compound (ProSciTech), snap-frozen using dry ice-cooled isopentane, and then stored at $-80^{\circ} \mathrm{C}$ until sectioning. Coronal sections (20 $\mu \mathrm{m}$ thick) were cut on a Leica cryostat CM3050-S, collected on Superfrost Plus slides (1:5 series; Lomb Scientific), and stored at $-80^{\circ} \mathrm{C}$ until staining.

Analysis of C5aR expression. Immunofluorescent staining techniques were used to assess the expression and distribution of $\mathrm{C} 5 \mathrm{aR}$ in the injured spinal cord. A rat anti-C5aR antibody (clone 10/92, 1:200; AbD Serotec) was used for these experiments. Antibody specificity was confirmed through staining of spinal cord tissue from injured $\mathrm{C}_{\mathrm{ar}} \mathrm{r}^{-1-}$ mice, as well as omission of the primary antibody incubation step on WT tissue. Staining for $\mathrm{C} 5 \mathrm{aR}$ was combined with immunolabeling for ionized calcium binding adaptor molecule 1 (rabbit anti-Iba1, 1:500; Wako Pure Chemical Industries) to label microglia/macrophages, or with GFAP (rabbit anti-GFAP, 1:1000; Dako) to identify astrocytes. Slides were defrosted for $1 \mathrm{~h}$ at room temperature (RT) and then washed in PBS $(3 \times 10 \mathrm{~min})$. Next, slides were incubated in blocking solution $(0.2 \%$ Triton X-100, Sigma-Aldrich; $2 \%$ BSA, Sigma-Aldrich; in PBS) for $1 \mathrm{~h}$ at RT to permeabilize the sections and reduce nonspecific antibody binding. This solution was also used as the antibody diluent. After blocking, spinal cord sections were incubated overnight at $4^{\circ} \mathrm{C}$ with primary antibodies in a humidified chamber. The following day, slides were washed in PBS $(3 \times$ $10 \mathrm{~min}$ ) to remove unbound antibody, followed by incubation with secondary antibodies goat anti-rat IgG-AlexaFluor-555 (1:500; Invitrogen) and goat anti-rabbit IgG-AlexaFluor-488 (1:200; Invitrogen) for $1 \mathrm{~h}$ at RT. Slides were then washed again in PBS $(3 \times 10 \mathrm{~min})$, coverslipped with Dako fluorescent mounting medium containing Hoechst 33342 nuclear dye (1:1000; Sigma-Aldrich), and imaged using an Olympus BX61 confocal microscope.

Assessment of functional recovery. Mouse hindlimb locomotor recovery in WT and $\mathrm{C}_{\mathrm{ar}}{ }^{-1-}$ mice was assessed at 1, 3, 7, 10, 14, 21, 28, and $35 \mathrm{~d}$ after injury using the 10 point Basso Mouse Scale (BMS), which is specifically designed for mouse models of SCI (Basso et al., 2006). Two investigators assessed various aspects of each mouse's locomotion in open field for $4 \mathrm{~min}$. For mice that achieved a score of frequent plantar stepping (i.e., a BMS score $\geq 5$ ), BMS subscores were also assigned to quantify the finer aspects of locomotion. For the initial experiments comparing the recovery of WT and conventional $\mathrm{C}_{\mathrm{aar}}^{-1-}$ mice, the actual applied force was $71.9 \pm 0.56 \mathrm{kdyne}(n=12$, mean \pm SEM $)$ and $72.2 \pm 0.52 \mathrm{kdyne}(n=8$, mean \pm SEM $)$, with an average tissue displacement of $593.4 \pm 6.57 \mu \mathrm{m}$ (mean \pm SEM) and $597.4 \pm 9.71 \mu \mathrm{m}$ (mean \pm SEM), respectively. There were no significant differences in injury parameters between experimental groups $(p>0.05)$. 
For pharmacological studies involving C5aR antagonism during the first week of injury (see C5aR-A treatment), ledged tapered beam walking was used as a second, independent measure to assess hindlimb locomotor ability. The beam itself, which was elevated $1 \mathrm{~m}$ above the floor, was $90 \mathrm{~cm}$ long and had a starting width of $3 \mathrm{~cm}$ that narrowed to $0.5 \mathrm{~cm}$ at the end. Mice were trained to cross the beam for 5 consecutive times during $2 \mathrm{~d}$ of habituation trials before the testing day. On the test day itself ( $35 \mathrm{~d}$ after SCI), each mouse was again required to cross the beam 5 times and videotaped while performing the task. The total number of steps, the number of footfalls, and the traversing time were recorded. For each animal, the mean data from the five crossings were calculated for each of these parameters. A group of sham-operated Macgreen mice $(n=6)$ was included to determine baseline performance for this functional task. Assessors were blinded to the experimental condition (genotype/treatment group) during all behavioral testing to avoid experimenter bias.

MRI. For postmortem MRI analysis at $35 \mathrm{~d}$ after injury, spinal cord samples were washed extensively in $0.1 \mathrm{M}$ PBS after overnight postfixing, followed by immersion for $48 \mathrm{~h}$ in PBS containing gadolinium contrast agent (0.2\% Magnevist, Bayer HealthCare Pharmaceuticals). Vertebral columns with the spinal cord in situ were imaged on a 16.4T small animal MRI (Bruker BioSpin) as detailed previously (Blomster et al., 2013b). A stack of 256 two dimensional T2 slices was generated for each imaged specimen. MRI datasets were analyzed using AVIZO version 6.2 software (Visualization Sciences Group), with an orthoslice along the sagittal plane and two user-defined (oblique) slices along the coronal and transverse planes, respectively. The Apply-Transform function was used to set these axes as the reference points for further analyses. A 3D image of the lesion core was reconstructed by manually outlining the hypointense core in the coronal plane of every slice using the Lasso tool; the sagittal and transverse planes were also viewed to confirm that the complete lesion core was highlighted. As areas of demyelination can be difficult to distinguish from remnants of spared gray matter, only the hypointense core was outlined for reconstruction and calculation of lesion volumes. Image quantification was performed with the investigator blinded to the experimental group.

General staining procedures and analysis of histopathology. FluoroMyelin Red staining (1:150; Invitrogen) was performed as per the manufacturer's instructions to assess white matter myelin content at and around the lesion site (Blomster et al., 2013a). FluoroMyelin Red staining was combined with immunostaining for GFAP as detailed above, except for experiments that involved Macgreen mice, where a separate set of sections were stained for GFAP using a goat anti-rabbit IgG-AlexaFluor546 secondary antibody (1:250; Invitrogen). Stained spinal cord sections were photographed using an Olympus SZX12 Research Fluorescence Stereo Microscope (Spectra Services). The proportional area of myelin and GFAP staining (relative to the section area) was measured using the freehand selection tool and threshold functions in ImageJ. The average pixel intensity for GFAP immunofluorescence was also determined as detailed previously (Schmid et al., 2013). For each experimental animal, the lesion epicenter was defined as the coronal section with the least amount of FluoroMyelin Red staining relative to the section area (Blomster et al., 2013a). Image acquisition and data analysis were again performed with experimenter blinding.

To evaluate the cellular immune response in the injured spinal cord, immunohistochemical staining with rat anti-Ly6b.2 (1:400; AbD Serotec) was used to visualize infiltrating neutrophils (and a subset of inflammatory monocytes) (Rosas et al., 2010). Rat anti-CD11b (1:200; AbD Serotec) was used to label granulocytes, macrophages, and microglia. Rat anti-CD3 (1:400; AbD Serotec) was used to stain T lymphocytes. For all of these stains, slides were first washed in PBS $(3 \times 10 \mathrm{~min})$. To quench endogenous peroxidase activity, slides were incubated at RT in PBS containing 10\% methanol for $10 \mathrm{~min}$ and then incubated for $20 \mathrm{~min}$ at RT in PBS containing $10 \%$ methanol and $0.3 \% \mathrm{H}_{2} \mathrm{O}_{2}$. Slides were then washed again in PBS $(3 \times 10 \mathrm{~min})$ and incubated with blocking solution for $1 \mathrm{~h}$ at RT, before overnight incubation with primary antibody in a humidified chamber at $4^{\circ} \mathrm{C}$. The following day, slides were washed in PBS and incubated for $1.5 \mathrm{~h}$ at RT with biotinylated donkey anti-rat IgG (1:250; $\mathrm{AbD}$ Serotec). Sections were then washed again in PBS $(3 \times 10 \mathrm{~min})$ and incubated with Vectastain Elite ABC reagent (1:200; Vector Laboratories) for $1 \mathrm{~h}$ at RT. After another set of $3 \times 10 \mathrm{~min}$ washes in PBS, the staining was developed by incubating each slide for $5 \mathrm{~min}$ at RT with 0.5 $\mathrm{ml}$ of 3,3-diaminobenzidine (Sigma-Aldrich). Stained sections were dehydrated through graded series of ethanol $(70 \%-100 \%)$, washed twice in xylene, and coverslipped using Depex mounting media (Electron Microscopy Sciences). Immunohistochemically stained slides were digitized using a ScanScope XT scanner (Aperio) and ImageScope (Leica Biosystems).

For quantitative analysis, Ly6b. $2^{+}$and $\mathrm{CD} 3{ }^{+}$cell numbers in the spinal cord were counted using the manual tag function in ImagePro Plus Version 6.3 (Media Cybernetics) and expressed as number of cells per $\mathrm{mm}^{2}$ based on the section area outlined in ImageJ. The CD11b ${ }^{+}$immune infiltrate was quantified and expressed as a proportional area of the section (Kigerl et al., 2006). The analyzer was blinded to the experimental condition during counting and image analysis.

C5aR-A treatment. A cohort of Macgreen mice was used for pharmacological inhibition of $\mathrm{C} 5 \mathrm{aR}$ during the acute/subacute phase. These mice underwent SCI as described above and then administered either the cyclic $\mathrm{C} 5 \mathrm{aR}$ peptide antagonist (C5aR-A; [hydrocinnamate(OPdChaWR)], $1 \mathrm{mg} / \mathrm{kg}$, i.p., $n=8$ ) (Finch et al., 1999) or a vehicle solution ( $5 \%$ glucose, i.p., $n=10$ ). Treatment started at $30 \mathrm{~min}$ after injury and was repeated every $12 \mathrm{~h}$ for the first $7 \mathrm{~d}$ after injury. The actual applied force for this experiment was $72.5 \pm 0.65 \mathrm{kdyne}$ and $72.5 \pm 0.54$ kdyne (mean \pm SEM) for vehicle-treated and C5aR-A-treated mice, respectively. The associated tissue displacement was $539.2 \pm 7.5 \mu \mathrm{m}$ and $528.7 \pm 12.4 \mu \mathrm{m}$ (mean $\pm \mathrm{SEM})$, respectively. There were no differences in injury parameters between groups $(p>0.05)$. These mice were subjected to BMS scoring, ledged tapered beam walking, and postmortem analysis of histopathology, all as detailed earlier.

In a separate experiment, WT mice were subjected to SCI and treated with either C5aR-A $(n=4)$ or vehicle $(n=5)$ as detailed above, every $12 \mathrm{~h}$ until the experimental endpoint of $21 \mathrm{~d}$ after SCI. The actual applied force here was $72.0 \pm 1 \mathrm{kdyne}$ (mean \pm SEM) for C5aR-A-treated mice and $72.60 \pm 0.68$ kdyne (mean $\pm \mathrm{SEM}$ ) for vehicle-treated controls; the associated tissue displacement was $534.7 \pm 25.9 \mu \mathrm{m}$ and $522.7 \pm 29.7$ $\mu \mathrm{m}$ (mean \pm SEM), respectively. A cohort of $\mathrm{C} 5 \mathrm{ar}^{-1-}$ mice $(n=5)$ was also included in this experiment; the applied force for these animals was $72.8 \pm 0.8 \mathrm{kdyne}$ (mean $\pm \mathrm{SEM}$ ), with an associated tissue displacement of $521.6 \pm 33.4 \mu \mathrm{m}$ (mean $\pm \mathrm{SEM})$. There were no differences in injury severity parameters between experimental groups $(p>0.05)$. All of the animals in this experiment were also injected with the thymidine analog BrdU (BD Biosciences, $50 \mathrm{mg} / \mathrm{kg}$, i.p.) every $24 \mathrm{~h}$ for the first $7 \mathrm{~d}$ after SCI to label proliferating cells (see below). This period was chosen for BrdU injection as it is thought to capture the onset of oligodendrocyte precursor cell and astrocyte proliferation after rodent CNS trauma (Bush et al., 1999; Zai and Wrathall, 2005; Lytle and Wrathall, 2007; Tripathi and McTigue, 2007; Wanner et al., 2013). Functional recovery in this experiment was monitored via BMS scoring with investigator blinding.

Cytokine quantification. For analysis of cytokine levels in acute SCI, the injured spinal cord segment (vertebral levels T8-T10) from both WT and $\mathrm{C}_{5 \mathrm{ar}^{-1-}}$ mice was collected at $12 \mathrm{~h}$ after SCI ( $n=5$ per group) and processed as detailed earlier (see C5a ELISA). This segment of spinal cord was also collected from sham-operated (i.e., laminectomy with no subsequent SCI) WT and C5ar ${ }^{-1-}$ mice to establish baseline cytokine levels ( $n=4$ per group).

The concentrations of CXCL1 and IL- $1 \beta$ in spinal cord supernatants were determined using cytokine Flex Sets (BD Biosciences, \#558340 and \#560232, respectively). Levels of IL-12p70, TNF $\alpha$, IFN $\gamma$, MCP-1, IL-10, and IL- 6 were also determined using a Cytometric Bead Array (BD Biosciences, \#552364) as per the manufacturer's instructions. The latter samples were analyzed on an LSRII flow cytometer (BD Biosciences), and concentrations computed using FCAP array version 3.0 software. For all assays, samples were appropriately diluted, such that they were always detected within the linear aspect of the standard curves. The calculated cytokine concentrations were normalized to the total protein content of each sample, which was measured by a BCA protein assay (Thermo Scientific, \#23227) according to the manufacturer's instructions. 
Flow cytometry. Flow cytometry was used to quantify the inflammatory infiltrate in the injured spinal cord at $7 \mathrm{~d}$ after SCI. In brief, injured spinal cord of WT and C5ar ${ }^{-1-}$ mice (T11-13 segments) was dissociated as reported previously (Beck et al., 2010; Blomster et al., 2013a). Cells were then resuspended in flow cytometry blocking buffer $(0.5 \%$ BSA, $2 \mathrm{~mm}$ EDTA, in DPBS, pH 7.2), followed by incubation with rat-anti-CD16/32 (1:200; BD Biosciences) for $10 \mathrm{~min}$ at $4^{\circ} \mathrm{C}$ to block $\mathrm{F}_{\mathrm{c}}$ receptors. Cells were immunolabeled with rat anti-Ly6G-Alexa-647 (1:200, BD Biosciences), rat anti-Ly6C-V450 (1:200; BD Biosciences), and rat antiCD45-PE (1:200; BD Biosciences). For the exclusion of dead cells, samples were also incubated with near infrared-conjugated viability dye (Zombie NIR, 1:100; BioLegend). Stained samples were then analyzed using an LSR II flow cytometer (BD Biosciences) and BD FACS Diva software. After acquisition, compensation was applied to remove Zombie NIR/Ly6G-Alexa-647 spectral overlap; cell doublets, triplets, etc. were excluded based on FSC-A/FSC-H linearity. Inflammatory monocytes/macrophages were defined as the $\mathrm{CD} 45^{\mathrm{hi}} \mathrm{Ly} 6 \mathrm{C}^{+} \mathrm{Ly} 6 \mathrm{G}^{-}$population, and neutrophils as the $\mathrm{CD} 45^{+} \mathrm{Ly} 6 \mathrm{C}^{+} \mathrm{Ly} 6 \mathrm{G}^{+}$population. Propidium iodide-fluorescing counting beads ( $5 \mu \mathrm{l}$; Beckman Coulter) were added as an internal control to enable quantification of absolute cell numbers according to the manufacturer's instructions.

Bone marrow (BM) chimeras. To assess the impact of selective C5aR deletion within the peripheral immune compartment on recovery from SCI, $[W T \rightarrow W T](n=6)$, and $\left[{\mathrm{C} 5 a r^{-1-}}^{\prime} \rightarrow W T\right](n=7)$ BM chimeric mice were generated as detailed previously (Chinnery et al., 2010). These mice were allowed to recover for 8 weeks after chimerization before being subjected to SCI surgery as detailed above. For this experiment, the actual applied force was $72.86 \pm 0.80 \mathrm{kdyne} \mathrm{versus} 72.29 \pm 0.87 \mathrm{kdyne}$ (mean \pm SEM), with an associated tissue displacement of 518.6 $\pm 14.9 \mu \mathrm{m}$ and $511.1 \pm 12.18 \mu \mathrm{m}($ mean $\pm \mathrm{SEM})$ for $[W T \rightarrow W T]$ and $\left[\mathrm{C} 5 \mathrm{ar}^{-1-} \rightarrow\right.$ $W T]$ BM chimeras, respectively. There were no significant differences in injury parameters between experimental groups $(p>0.05)$. SCI outcomes for these mice were assessed via BMS scoring and postmortem analysis of histopathology as detailed earlier.

Assessment of glial cell proliferation and apoptosis. Spinal cord tissue from mice that were chronically treated with C5aR-A, and also administered BrdU during the first week following SCI, was used to determine whether C5aR targeting influenced the proliferative response(s) of oligodendrocyte precursor cells and astrocytes (study endpoint: $21 \mathrm{~d}$ after SCI). Immunofluorescent staining of spinal tissue was done using similar procedures as described above, but with the inclusion of a denaturing step $\left(20\right.$ min incubation in $2 \mathrm{~N} \mathrm{HCl}$ at $37^{\circ} \mathrm{C}$ ) to expose the $\mathrm{BrdU}$ epitope within the nuclear DNA. After blocking, sections were probed with rat anti-BrdU antibody (1:100; AbD Serotec) in combination with rabbit anti-GFAP (1:1000; Dako) for astrocytes, or mouse anti-CC1 (1:100; Abcam) for oligodendrocytes. For the latter, the HistoMouse kit (Invitrogen) was used as per the manufacturer's instructions to allow for the use of mouse primary antibodies on mouse tissue. An incubation with biotinylated donkey anti-rat IgG (1:200; Vector Laboratories) secondary antibody ( $1 \mathrm{~h}$ at RT) was followed by a $1 \mathrm{~h}$ incubation with streptavidinAlexaFluor-546 (1:200; BD Biosciences), combined with either goat antirabbit IgG-AlexaFluor-488 (1:200; Invitrogen) for GFAP staining or with goat anti-mouse IgG-AlexaFluor-488 (1:200; Invitrogen) for CC1 staining. Tiled optical sections were captured on a Zeiss fluorescence microscope with ApoTome attachment, after which the total $\mathrm{BrdU}^{+} \mathrm{GFAP}^{+}$or $\mathrm{BrdU}^{+} \mathrm{CC}^{+}$cell numbers were counted in spinal cord cross-sections at regular intervals away from the lesion epicenter, with the analyzer being blinded to the experimental condition. Section areas were measured in ImageJ (up to $1 \mathrm{~mm}$ in rostral and caudal directions), allowing the cell count to be expressed as number of cells per $\mathrm{mm}^{2}$. Lesion volumes in these animals were estimated by outlining the lesion core area (delineated by GFAP staining) in every relevant section using ImageJ; obtained values were then multiplied by the section thickness and totaled for each animal.

To also compare and contrast oligodendrocyte cell death between the various genotypes and/or experimental conditions at the study endpoint, a separate set of sections were stained for $\mathrm{CC} 1$ and active Caspase-3 (anti-Cleaved Caspase-3 rabbit polyclonal; 1:200; BD Biosciences PharMingen). The number of $\mathrm{CC} 1^{+}$Cleaved Caspase $-3^{+}$cells were then counted within each section and expressed as the number of cells per $\mathrm{mm}^{2}$ based on the section area outlined in ImageJ. The analyzer was again blinded to the experimental condition during analysis.

In vitro astrocyte proliferation. Astrocyte cultures were established from the brains of WT or C5ar ${ }^{-1-}$ pups (P1-P3; $n=8$ per culture) (Gordon et al., 2011). In brief, brains were harvested, the meninges removed, and the tissue placed in ice-cold DMEM/F-12 nutrient mixture (Invitrogen, \#11320) supplemented with 10\% heat-inactivated FBS, 50 $\mathrm{U} / \mathrm{ml}$ penicillin, $50 \mu \mathrm{g} / \mathrm{ml}$ streptomycin, $2 \mathrm{~mm}$ L-glutamine, $100 \mu \mathrm{M}$ nonessential amino acids, and $2 \mathrm{~mm}$ sodium pyruvate (Invitrogen). The tissue was then incubated in $0.25 \%$ trypsin (Sigma-Aldrich) at $37^{\circ} \mathrm{C}$ for 30 min with gentle agitation. Trypsinization was stopped by adding an equal volume of DMEM/F12 complete media, followed by three washes in the same media. A single-cell suspension of the tissue was prepared by gentle trituration and passing of the solution through a $70 \mu \mathrm{m}$ nylon mesh cell strainer to remove tissue debris and aggregates, after which the remaining cell suspension was seeded into two T-75 flasks per mouse brain. Primary astrocytes were purified by daily media changes for $3 \mathrm{~d}$ and residual microglial cells were maximally depleted by treatment with the lysosomotropic agent leucine methylester $(5 \mathrm{~mm})$ for $6 \mathrm{~h}$ to obtain $\sim 98 \%$ pure astrocytes. The purity of astrocyte cultures was routinely verified by immunocytochemistry for GFAP and Ibal.

For the proliferation assay, purified astrocytes were plated out at a density of either 0.5 or $1 \times 10^{4}$ cells per well in a 48 well plate with media containing DMEM/F12, 10\% FBS, 1\% nonessential amino acids, $1 \%$ penicillin/streptomycin, $1 \% \mathrm{~L}$-glutamine, and $1 \%$ sodium pyruvate. The next day, cells were switched to media containing $2 \% \mathrm{FBS}$, and recombinant mouse C5a (Hycult Biotech) was added at a concentration of 0, 5, $10,50,100$, or $200 \mathrm{~nm}$ in triplicate. For experiments that aimed to determine whether phosphorylation of Signal Transducer and Activator of Transcription 3 (STAT3) was involved in astrocyte proliferation in the presence of C5a, $5 \mu \mathrm{M}$ of the STAT3 inhibitor (BP-1-102, Millipore) was added $10 \mathrm{~min}$ before C5a (50 nM) exposure; BP-1-102 disrupts STAT3STAT3 dimerization and STAT3-phospho-tyrosine (pTyr) peptide interactions (Zhang et al., 2012). Plates were then incubated for $48 \mathrm{~h}$ under standard cell culture conditions $\left(37^{\circ} \mathrm{C}, 5 \% \mathrm{CO}_{2}\right)$. The extent of astrocyte proliferation under the various experimental conditions was measured using a CyQUANT assay (Invitrogen) according to the manufacturer's instructions.

Western blotting. Separate sets of astrocyte cultures were established and randomly allocated to one of the following groups: (1) no treatment, (2) $50 \mathrm{~nm}$ C5a only, (3) $50 \mathrm{~nm} \mathrm{C5a}+10 \mu \mathrm{M} \mathrm{BP-1-102} \mathrm{(STAT3-inhibitor),}$ and (4) $10 \mu \mathrm{M}$ BP-1-102 only. Astrocytes were exposed to C5a for $1 \mathrm{~h}$; where applicable, BP-1-102 was added to the culture medium $10 \mathrm{~min}$ before C5a exposure. After incubation, cells were scraped off the flasks and collected via (low-speed) centrifugation at $300 \times g$ for $6 \mathrm{~min}$. Supernatants were removed and the cell pellets stored at $-80^{\circ} \mathrm{C}$ until lysis in $150 \mu$ l of modified RIPA buffer containing the following: $10 \mathrm{~mm}$ Tris, 100 mm NaCl, 1 mm EDTA, 1 mm EGTA, 1 mm NaF, 20 nM Na ${ }_{4} \mathrm{P}_{2} \mathrm{O}_{7}, 2 \mathrm{~nm}$ $\mathrm{Na}_{3} \mathrm{VO}_{4}, 0.1 \%$ SDS, $0.5 \%$ sodium deoxycholate, $1 \%$ Triton X-100, $10 \%$ glycerol, and $10 \mu \mathrm{l} / \mathrm{ml}$ Halt protease/phosphatase inhibitor mixture (Thermo Scientific). Cell lysates were vortexed for $1 \mathrm{~min}$ at RT, incubated on ice for $30 \mathrm{~min}$, and then centrifuged for $30 \mathrm{~min}$ at $4^{\circ} \mathrm{C}$ to remove debris. The protein concentration in the supernatant was determined using a standard BCA protein assay (Thermo Scientific).

The Bio-Rad electroblotting system was used for Western blotting experiments. To determine the ratio of phosphorylated STAT3 (PSTAT3) to STAT3, $30 \mu \mathrm{g}$ of protein was diluted 1:3 in loading buffer (250 mM Tris $\mathrm{HCl}, 8 \%$ SDS, $0.008 \%$ bromophenol blue, $20 \%$ $\beta$-mercaptoethanol, $40 \%$ glycerol, $\mathrm{pH} 6.8$ ), heated to $96^{\circ} \mathrm{C}$ for $4 \mathrm{~min}$, and then stored on ice for $5 \mathrm{~min}$. Samples and dual-color protein standards (Bio-Rad) were separated on 10\% SDS-polyacrylamide gels using a $3 \mathrm{~A}$ (114 V) current in running buffer (0.19 M Tris, $1.92 \mathrm{M}$ glycine, $0.35 \mathrm{M}$ SDS in $\mathrm{ddH}_{2} \mathrm{O}$ ) for $1 \mathrm{~h}$. Immobilon PVDF membranes (Millipore) were primed with a $15 \mathrm{~s}$ wash in methanol, followed by a 2 min wash in $\mathrm{ddH}_{2} \mathrm{O}$ and a $5 \mathrm{~min}$ wash in transfer buffer (4.68 $\mathrm{M}$ methanol in running buffer). Proteins were then transferred over $1 \mathrm{~h}$ onto the membranes using a $3 \mathrm{~A}$ $(100 \mathrm{~V})$ current in transfer buffer. After the transfer, membranes were washed $(3 \times 10 \mathrm{~min})$ in Tris-buffered saline (TBS)-Tween (TBST; $50 \mathrm{~mm}$ Tris, $150 \mathrm{~mm} \mathrm{NaCl}, 0.05 \%$ Tween 20), followed by blocking in Odyssey 
blocking buffer (LI-COR) for $1 \mathrm{~h}$ at RT on a rotator. Membranes were then cut and probed with primary antibodies against $\beta$-actin (1:1000; Cell Signaling Technology, \#4967) and anti-STAT3 (79D7) (1:2000; Cell Signaling Technology, \#4904) overnight at $4^{\circ} \mathrm{C}$ on a rotator. The following morning, membranes were washed on a rotator at RT $(3 \times 10 \mathrm{~min}$ in TBST). Next, membranes were incubated with secondary antibody (goat anti-rabbit IgG-IRDye 800CW (1:20,000; LI-COR, \#926-32211) for $1 \mathrm{~h}$ at $\mathrm{RT}$ on a rotator. After $3 \times 10 \mathrm{~min}$ washes in TBST, blots were imaged using the Odyssey Infrared Imaging System (LI-COR). Bound antibodies were then stripped from the membrane using Newblot PVDF stripping buffer (LI-COR, \#928-40032) as per the manufacturer's instructions, and the membranes incubated again for $10 \mathrm{~min}$ on a rotator in Odyssey blocking buffer (LI-COR). Membranes were then washed $(3 \times 10 \mathrm{~min}$ in TBST) and probed for $\beta$-actin (1:1000; Cell Signaling Technology, \#4967) and P-STAT3 (1:1000; Cell Signaling Technology, \#9131) overnight at $4^{\circ} \mathrm{C}$. The next morning, blots were washed $(3 \times 10 \mathrm{~min}$ in TBST) and incubated with secondary antibody (goat anti-rabbit IgG-IRDye 800CW, 1:20,000; LI-COR, \#926-32211) for $1 \mathrm{~h}$ at RT on a rotator. After another series of washes in TBST, blots were imaged again using the Odyssey Infrared Imaging System (LI-COR). The ratio of P-STAT3 to STAT3 in each lane was calculated after normalization to the $\beta$-actin band using the Analyze Gel function in ImageJ.

To confirm C5aR expression by cultured astrocytes, $40 \mu \mathrm{g}$ of protein was loaded into the Bio-Rad electroblotting system. Rat anti-C5aR antibody (clone 10/92; 1:1000; Hycult Biotech, \#HM1077), in combination with goat anti-rat IgG IRDye-700CW (1:10,000; LI-COR, \#926-32219), was used to detect $\mathrm{C} 5 \mathrm{aR}$ using similar procedures as detailed above. After stripping, blots were probed for $\beta$-actin (1:1000; Cell Signaling Technology, \#4967) followed by goat anti-rabbit IgG-IRDye 800CW (1:20,000; LI-COR, \#926-32211) to control for loading and confirm appropriate protein transfer. WT mouse brain homogenate was used as a positive control. Protein homogenized from $\mathrm{C}_{5} \mathrm{ar}^{-1-}$ mouse brain was also included to confirm again the specificity of the antibody that was used to detect C5aR.

Statistical analysis. GraphPad Prism (GraphPad Software) was used for all data visualization and statistical analyses. In vivo BMS data were analyzed using two-way repeated-measures ANOVA with Bonferroni post hoc tests. Two-sided Student's $t$ tests were used to directly compare differences in lesion size and/or histological data (myelin, GFAP, Ly6b.2, CD11b, and CD3 staining) at the lesion epicenter. Data from the narrowing beam walk, in vitro cell culture, and Western blot experiments were analyzed using one-way ANOVA with Newman-Keuls post hoc tests. For the comparison of $\mathrm{C} 5 \mathrm{a}$ levels in the spinal cord and blood plasma, in vivo glial cell proliferation/survival, Ly6b. $2^{+}$and $\mathrm{CD} 3{ }^{+}$cell numbers along the length of the injured cord, and cytokine levels between experimental groups/conditions, two-way ANOVA with Newman-Keuls post hoc test was used. Pearson's correlation test was used to examine the relationship between astrocyte proliferation and lesion size, and for correlating lesion volume, myelin or GFAP staining with BMS scores. All data are mean \pm SEM, with statistical significance determined at $p<0.05$.

\section{Results}

\section{C5a production and expression of $\mathrm{C} 5 \mathrm{aR}$}

C5a levels in homogenized spinal cord and plasma samples were measured by ELISA to determine the temporal profile of complement activation after SCI. Baseline C5a levels were low (2.6 \pm $0.25 \mathrm{pg} / \mu \mathrm{g}$ protein) in spinal cord samples from unoperated mice (time point 0 ). C5a levels in samples from naive mice were not different from samples from sham-operated mice at any time point after surgery $(p>0.05)$. Following SCI, a rapid and dramatic increase in tissue C5a levels was observed, which peaked at $1 \mathrm{~d}$ after injury $(9.3 \pm 1.4 \mathrm{pg} / \mu \mathrm{g}$ protein, a 4.5 -fold increase over sham-operated controls). Spinal cord C5a levels were still significantly higher in SCI mice compared with sham-operated controls at $4(7.0 \pm 1.1 \mathrm{vs} 2.2 \pm 0.68 \mathrm{pg} / \mu \mathrm{g}$ protein $)$ and $7 \mathrm{~d}(6.1 \pm$ 0.85 vs $1.8 \pm 0.63 \mathrm{pg} / \mu \mathrm{g}$ protein) after surgery (Fig. $1 A$ ). Tissue C5a levels remained slightly elevated at $35 \mathrm{~d}$ after SCI, but this was not statistically significant compared with sham-operated mice when using ANOVA. In the plasma, a rapid increase in circulating C5a levels was observed following SCI, with these being significantly elevated above the amount of C5a present in matching samples from sham-operated mice at $30 \mathrm{~min}, 2 \mathrm{~h}, 6 \mathrm{~h}, 12 \mathrm{~h}$, and $1 \mathrm{~d}$ after surgery (Fig. $1 B$ ). Although still elevated, C5a levels were no longer different between sham and SCI mice from $4 \mathrm{~d}$ after injury onwards.

Immunofluorescent staining was used to examine the pattern and distribution of $\mathrm{C} 5 \mathrm{aR}$ expression in the injured spinal cord. At $1 \mathrm{~d}$ after SCI, prominent C5aR staining was observed on surviving $\mathrm{Iba}^{+}$microglia and population of smaller, round/ovoid Iba1 cells that are most likely infiltrating neutrophils (Fig. 1C). At $7 \mathrm{~d}$ after SCI, C5aR staining was apparent on cells with amoeboid and ramified morphology. Staining with Ibal indicated that many of these cells were activated microglia and clustered macrophages (Fig. 1D). C5aR staining also localized to a subset of $\mathrm{GFAP}^{+}$ astrocytes in the rim of spared white matter surrounding the lesion core (Fig. 1E). No C5aR staining was present on injured spinal cord tissue from $\mathrm{C}_{5 \mathrm{ar}}^{-1-}$ mice (Fig. $1 F$ ), indicating antibody specificity. Expression of C5aR by astrocytes was also confirmed in vitro through Western blotting (Fig. $1 G$ ).

\section{Genetic ablation of $\mathrm{C} 5 \mathrm{aR}$ reveals a dual role for $\mathrm{C} 5 \mathrm{a}$ signaling in SCI}

BMS locomotor scoring with experimenter blinding was performed on $\mathrm{C}_{5 \mathrm{ar}}{ }^{-1-}$ and WT mice for 5 weeks after injury to determine the contribution of C5aR to SCI outcomes. Before SCI, all mice displayed normal overground locomotion, achieving BMS scores of 9. SCI produced near-complete paralysis (BMS scores $0-1$ ) in all mice at $1 \mathrm{~d}$ after SCI. By $7 \mathrm{~d}$ after SCI, C5ar ${ }^{-1-}$ mice displayed significantly more hindlimb motor function than WT mice $(p<0.05)$ (Fig. $2 A, B)$. These early improvements were, however, not sustained and no longer present by $10 \mathrm{~d}$ after SCI. Indeed, by $21 \mathrm{~d}$ after SCI, C5ar ${ }^{-1-}$ mice now showed signs of impaired functional recovery, and their BMS scores were significantly below those of WT mice at 28 and $35 \mathrm{~d}$ after injury (Fig. $2 A, C)$. Endpoint postmortem analysis of lesion volume and histopathology provided additional support of an ultimately poorer outcome as a result of C5aR ablation. Specifically, a reconstruction of the lesion site from ex vivo MRI datasets revealed significantly larger lesion core volumes in $\mathrm{C}_{\mathrm{aar}}^{-1-}$ mice compared with WT mice at $35 \mathrm{~d}$ after SCI (Fig. $2 D, E ; p=0.023$ ). Lesion core volumes in WT and C5ar ${ }^{-1-}$ mice were negatively correlated with the BMS scores of individual animals at the study endpoint $\left(r^{2}=0.71 ; p=0.002\right)$.

In addition, FluoroMyelin Red staining revealed a reduction in myelin content in C5ar ${ }^{-1-}$ mice (Fig. 2F, G; $p=0.012$ ). $\mathrm{GFAP}^{+}$immunoreactivity (Fig. $2 F$ ) was also found to be reduced in $\mathrm{C}_{5 \mathrm{ar}}^{-1-}$ mice at $35 \mathrm{~d}$ after injury with regards to both the immunoreactive area (Fig. $2 H ; p=0.0073$ ) and the intensity of GFAP staining (Fig. $2 I ; p=0.017$ ). FluoroMyelin and GFAP staining at the lesion epicenter of WT and $C 5 \mathrm{ar}^{-1-}$ mice was positively correlated with BMS scores at the study endpoint $\left(r^{2}=0.73\right.$ and $r^{2}=0.51$, respectively; $\left.p<0.003\right)$. Last, a more widespread presence of Ly6b. $2^{+}$cells (Fig. $2 J ; p=0.0007$ ) and $\mathrm{CD}^{+}$T cells (Fig. $2 K ; p=0.0057$ ) was observed along the length of the spinal cord at the study endpoint.

\section{Acute but not sustained C5aR antagonism improves SCI outcomes}

Because the genetic ablation of C5aR appeared beneficial during the (sub)acute period of SCI, it was hypothesized that transient 


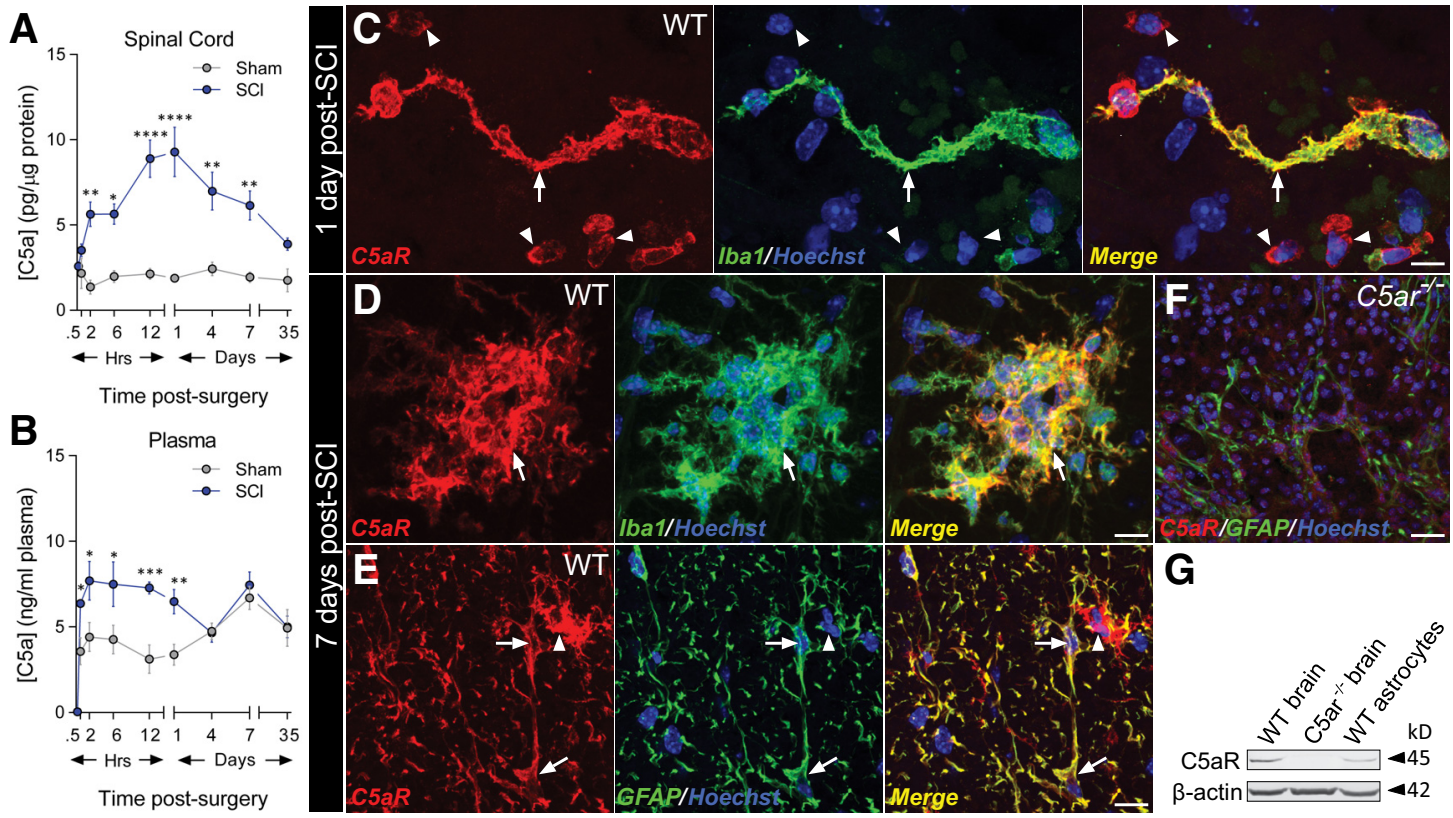

Figure 1. Production of $\mathrm{C} 5 \mathrm{a}$ and expression of $\mathrm{C} 5 \mathrm{aR}$ in the injured spinal cord. $A, \mathrm{C}$ a protein concentration in injured WT spinal cord is significantly increased compared with both naive (time point 0 ) and sham levels at $2 \mathrm{~h}, 6 \mathrm{~h}, 12 \mathrm{~h}, 1 \mathrm{~d}, 4 \mathrm{~d}$, and $7 \mathrm{~d}$ after SCI ( $n=4$ or 5 per time point, two-way ANOVA with Newman-Keuls post hoc tests). ${ }^{*} p<0.05$. ${ }^{* *} p<0.01 .{ }^{* * *} p<0.0001 . \boldsymbol{B}$, WT $5 \mathrm{a}$ levels are also increased in the plasma in response to SCl, exceeding levels observed in sham-operated mice at $30 \mathrm{~min}, 2 \mathrm{~h}, 6 \mathrm{~h}, 12 \mathrm{~h}$, and $1 \mathrm{~d}$ after injury ( $n=4$ or 5 per time point, two-way ANOVA with Newman-Keuls post hoc tests). ${ }^{*} p<0.05 .{ }^{* *} p<0.01 .{ }^{* * *} p<0.001$. C $-\boldsymbol{E}$, Representative confocal images showing (5aR expression in the injured spinal cord at 1 and $7 \mathrm{~d}$ after injury. $\boldsymbol{C}$, At $1 \mathrm{~d}$ after injury, C5aR appeared present at the lesion epicenter on nucleated Iba ${ }^{+}$cells (arrow) as well as numerous smaller circular/ovoid cells that did not express Iba 1 (arrowheads). Scale bar, 6.0 $\mu \mathrm{m} . \boldsymbol{D}$, At $7 \mathrm{~d}$ after injury, C5aR is present on cells with amoeboid morphology in WT mice, which appear to be clustered lba ${ }^{+}$macrophages/microglia (arrow). Scale bar, $10 \mu \mathrm{m} . \boldsymbol{E}$, C5aR expression was also observed on more elongated GFAP ${ }^{+}$astrocytes (arrows), alongside $\mathrm{CaR}^{+} \mathrm{GFAP}^{-}$cells with macrophage-like morphology (arrowhead). Scale bar, $13 \mu \mathrm{m}$. $\boldsymbol{F}$, Only a very low level of nonspecific background fluorescence was observed following $\mathrm{C5aR}$ staining of lesioned $\mathrm{C5ar}^{-1-}$ spinal cord tissue. Scale bar, $35 \mu \mathrm{m}$. G, Representative Western blots demonstrating C5aR expression by astrocytes in vitro. Left and middle lanes contain WT and $\mathrm{C}_{\mathrm{ar}}{ }^{-1-}$ whole mouse brain homogenates, respectively. Right lane contains protein sample from cultured WT astrocytes.

pharmacological blockade of C5aR during only the first $7 \mathrm{~d}$ after SCI would lead to sustained improvements in SCI recovery. Similar to $\mathrm{C}_{\mathrm{aar}}^{-1-}$ mice, administration of C5aR-A to Macgreen mice with SCI during the first week of injury resulted in a clear trend for improved recovery compared with vehicle-treated Macgreen mice. This improvement was sustained into the more chronic phase of injury and significantly different from vehicletreated controls at 21, 28, and $35 \mathrm{~d}$ after injury $(p<0.05)$ (Fig. $3 A, B)$. The ledged tapered beam walk test was also used at the study endpoint as a second, independent measure of the efficacy of (sub)acute C5aR-A treatment. Sham-operated control mice had no difficulty mastering this task, making very few mistakes and crossing the beam relatively fast (Fig. 3C,D). Although SCI consistently led to impaired performance in this test, C5aR-Atreated mice made significantly fewer stepping mistakes $(p=$ 0.0024; Fig. $3 C)$ and also traversed the beam faster $(p=0.017)$ (Fig. 3D) compared with vehicle-treated mice with SCI. Histological assessment of injured spinal cords at $35 \mathrm{~d}$ after SCI confirmed attenuated pathology as a result of (sub)acute C5aR-A treatment, with C5aR-A-treated mice having significantly more myelin content compared with the vehicle-treated animals (Fig. $3 E, F ; p=0.0088)$. The $\mathrm{GFP}^{+}$infiltrate in the lesion core was also significantly reduced ( $p=0.0061$; Fig. $3 E, G)$. There was, however, no difference in the GFAP ${ }^{+}$area $(p=0.67$; Fig. $3 H, I)$ or staining intensity $(p=0.48$; Fig. $3 H, J)$ between groups. Collectively, these data indicate that $\mathrm{C} 5 \mathrm{aR}$ antagonism, when limited to a 7 day window during the (sub)acute period of SCI, leads to improvements in neurological recovery that are sustained into the chronic phase of injury.

Importantly, continued antagonism of C5aR beyond the first week of injury in WT mice produced a phenotype similar to that of $\mathrm{C} 5 \mathrm{ar}^{-1-}$ mice. Specifically, an early trend toward improved recovery after $\mathrm{C} 5 \mathrm{aR}-\mathrm{A}$ treatment was again observed at $7 \mathrm{~d}$ after SCI, but this did not persist into the more chronic phase (Fig. $3 \mathrm{~K}$ ). Thus, the benefits of therapeutically targeting C5aR are annulled if blockade is maintained beyond the first week of spinal trauma.

\section{$\mathrm{C5ar}^{-1-}$ mice have reduced levels of proinflammatory} cytokines and attenuated macrophage recruitment early after SCI

To begin exploring why there were consistent signs of improved recovery during the (sub)acute phase in the absence of $\mathrm{C} 5 \mathrm{aR}$ signaling, we first investigated whether the inflammatory response to SCI was altered by C5aR ablation. We theorized that a dampened production of proinflammatory cytokines acutely after SCI may have yielded neuroprotection, which in turn underpinned the early functional improvements seen in $\mathrm{C} \mathrm{ar}^{-1-}$ mice. A cytometric bead array (BD Biosciences) was therefore used to measure the concentration of a panel of cytokines within the injured spinal cord of WT and $\mathrm{C}^{\mathrm{aar}}{ }^{-1-}$ mice at $12 \mathrm{~h}$ after SCI. This time point was specifically selected because various key proinflammatory cytokines are elevated or at peak concentrations here (Pineau and Lacroix, 2007); it also precedes the peak of the first wave of peripheral immune cell infiltration (i.e., neutrophils) (Kigerl et al., 2006; Beck et al., 2010), thereby allowing some differentiation between leukocyte-derived and glial/neuronally derived cytokines. There was no difference in baseline (i.e., sham-surgery) levels of any cytokine between WT and $C 5 \mathrm{ar}^{-1-}$ mice $(p>0.05)$. In both genotypes, SCI elicited significant increases in spinal cord levels of MCP-1 (Fig. 4A), TNF (Fig. 4B), CXCL1 (Fig. 4C), IL-6 (Fig. 4D), IL-1 $\beta$ (Fig. 4E), and IL-10 (Fig. 

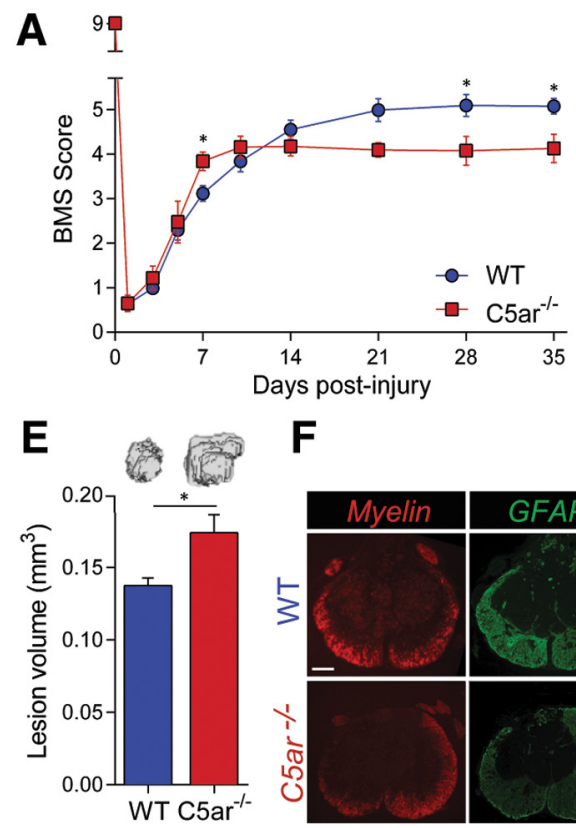

$F$
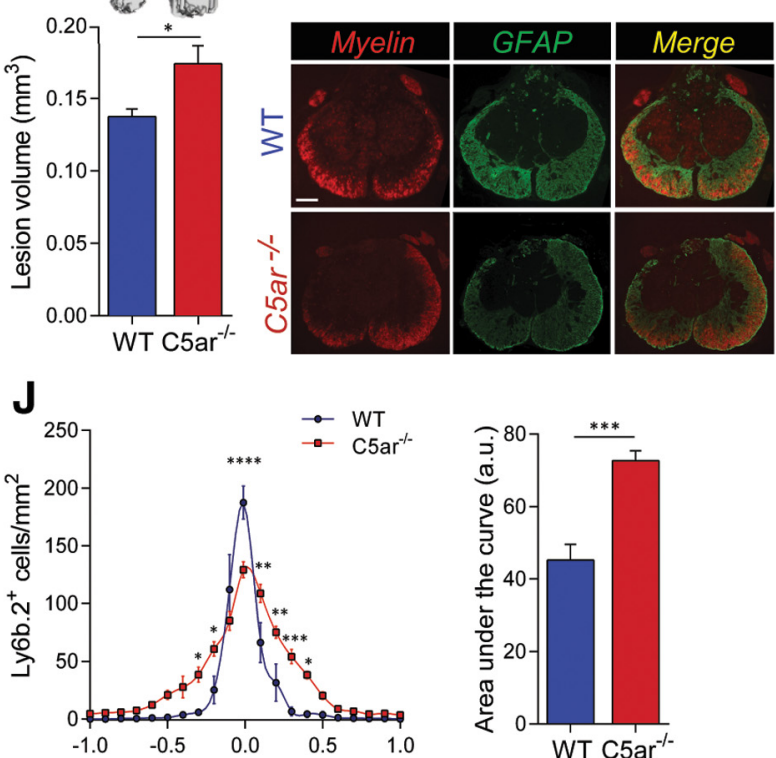

Distance from lesion epicentre $(\mathrm{mm})$
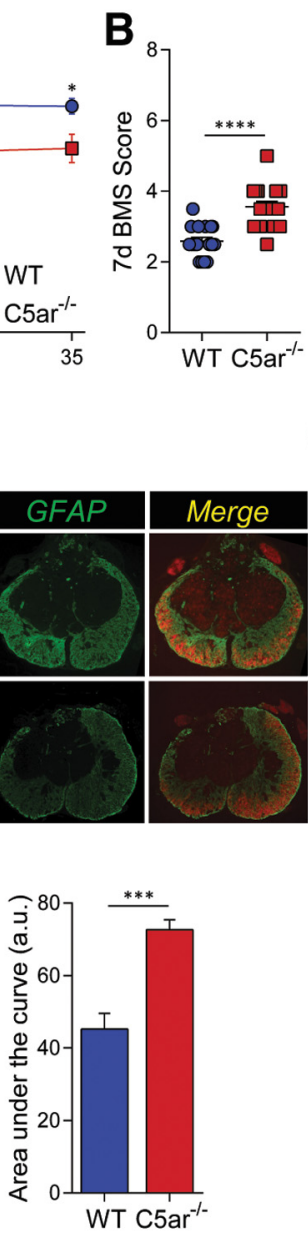
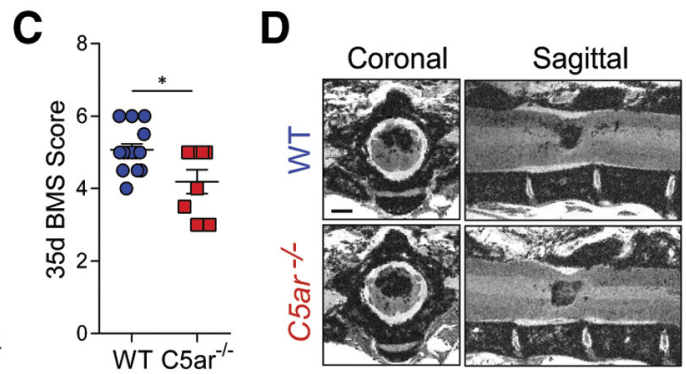

G
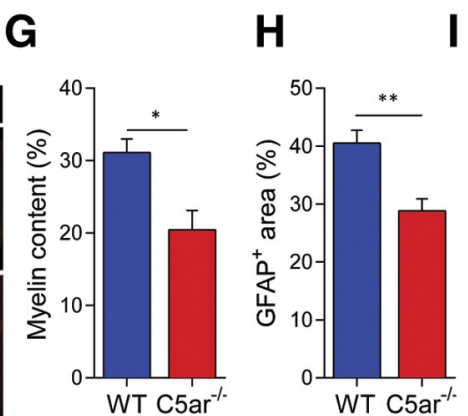

I

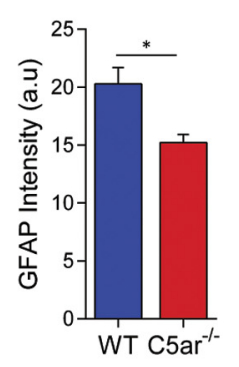

K

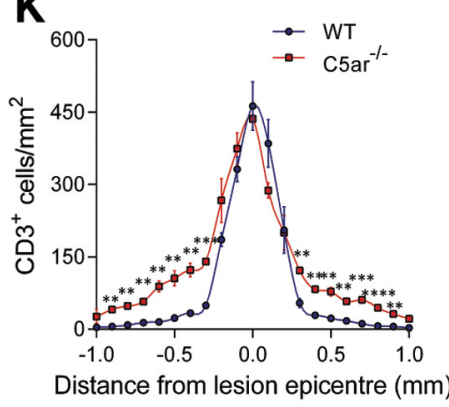

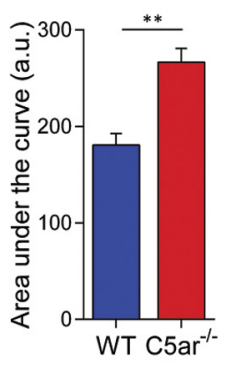

Figure 2. $\quad \mathrm{C}_{\mathrm{ar}}^{-1-}$ mice have a dual phenotype after $\mathrm{SCl}$. A, BMS locomotor scoring revealed that $\mathrm{C}^{-1} \mathrm{r}^{-1-}$ mice have significantly improved hindlimb motor function at $7 \mathrm{~d}$ after injury compared with WT mice. This trend reversed with time such that, at 28 and $35 \mathrm{~d}$ after SCl, WT mice had regained significantly more motor function than C5ar $^{-1}$ - mice (two-way ANOVA with Bonferroni post hoc tests, $n=8-12$ ). B, Pooled BMS scores for individual mice from various experiments at $7 \mathrm{~d}$ after injury (Student's two-sided $t$ test, $n=18-21$ ). $C$, Graph showing the BMS scores for individual mice at $35 \mathrm{~d}$ after injury from longitudinal scores plotted in $\boldsymbol{A}$ (Student's two-sided $t$ test, $n=8-12$ ). $\boldsymbol{D}$, Postmortem T ${ }_{2}{ }^{*}$-weighted MRI images showing lesion sites in WT and $\mathrm{C} \mathrm{ar}^{-1-}$ mice. Scale bar (top left image): coronal images, $400 \mu \mathrm{m}$; sagittal images, $1 \mathrm{~mm}$. $\boldsymbol{E}$, Quantitative analysis revealed significantly larger lesion core volumes in (5ar ${ }^{-1-}$ mice. Represen-

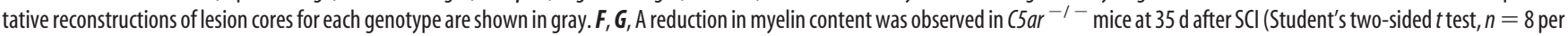

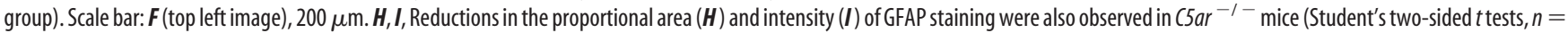
8 per group). $\boldsymbol{J}, \boldsymbol{K}$, A more widespread presence of Ly6b. $2^{+}$cells $(\boldsymbol{J})$ and CD3 ${ }^{+}$T cells $(\boldsymbol{K})$ was observed in $\left(5 a r^{-1-}\right.$ mice at 35 d after injury (tw0-way ANOVA with Newman-Keuls post hoc tests, $n=5$ per group), as also confirmed by area under the curve analysis (Student's two-sided $t$ test, $n=5$ per group). ${ }^{*} p<0.05 .{ }^{* *} p<0.01 .{ }^{* * *} p<0.001 .{ }^{* * *} p<0.0001$.

$4 F)$ over baseline. IL-12p70 and IFN $\gamma$ levels were not increased in response to SCI at this time point in either genotype (data not shown). Notably, many SCI-induced changes in cytokine levels were attenuated in the absence of $\mathrm{C} 5 \mathrm{aR}$, with significant reductions observed in CXCL1 (40\%, $p<0.05)$, IL-6 (33\%, $p<$ $0.01)$, and IL- $\beta$ (75\%, $p<0.0001)$ levels within the injured spinal cord.

We also quantified the number of granulocytes and inflammatory monocytes/macrophages at 1 and $7 \mathrm{~d}$ after injury (i.e., time points that represent the respective peak recruitment/infiltration times for these cells). Immunolabeling of Ly6b. $2^{+}$cells (which predominantly represent neutrophils acutely after injury) revealed no statistically significant reduction in the recruitment of these cells between genotypes at $1 \mathrm{~d}$ after SCI (Fig. $4 G ; p=$ 0.11 ). Flow cytometric analysis of the spinal cord at $7 \mathrm{~d}$ after SCI also showed no significant difference in the $\mathrm{Ly}_{6 \mathrm{G}}{ }^{+}$infiltrate between genotypes ( $p=0.07$; Fig. $4 H$ ). There was, however, a clear reduction in the number of CD45 ${ }^{\text {hi }} \mathrm{Ly}_{6 \mathrm{C}}{ }^{+} \mathrm{Ly} 6 \mathrm{G}^{-}$cells (inflammatory monocytes/macrophages) in $\mathrm{C}_{5 \mathrm{ar}}{ }^{-1-}$ mice at this time point ( $p=0.002$ ) (Fig. $4 I)$. In summary, these findings indicate that acute disabling of the $\mathrm{C} 5 \mathrm{a}-\mathrm{C} 5 \mathrm{aR}$ axis significantly reduces local proinflammatory cytokine production and the recruitment of inflammatory monocytes/macrophages.

\section{Lack of $\mathrm{C} 5 \mathrm{aR}$ in the peripheral immune compartment does not affect SCI outcomes}

Having observed a clear dual and time-dependent role for $\mathrm{C} 5 \mathrm{aR}$ in the response to SCI, we next aimed to better understand the mechanisms resulting in this phenotype. To this end, BM chimeric mice were generated to better appreciate the role of $\mathrm{C} 5 \mathrm{aR}$ expression within the peripheral immune compartment (i.e., circulating leukocytes) with regards to SCI outcomes (Fig. 5A). BMS locomotor scoring with experimenter blinding revealed that transplantation of $\mathrm{C} \mathrm{ar}^{-1-} \mathrm{BM}$ into conditioned WT hosts $\left(\left[\mathrm{C} 5 \mathrm{ar}^{-1-} \rightarrow W T\right]\right.$ BM chimeras) did not lead to altered recovery from SCI compared with $[W T \rightarrow W T]$ chimeras mice for up to at least $35 \mathrm{~d}$ after SCI (Fig. 5B,C). There were also no statistically significant differences in lesion histopathology, including the 


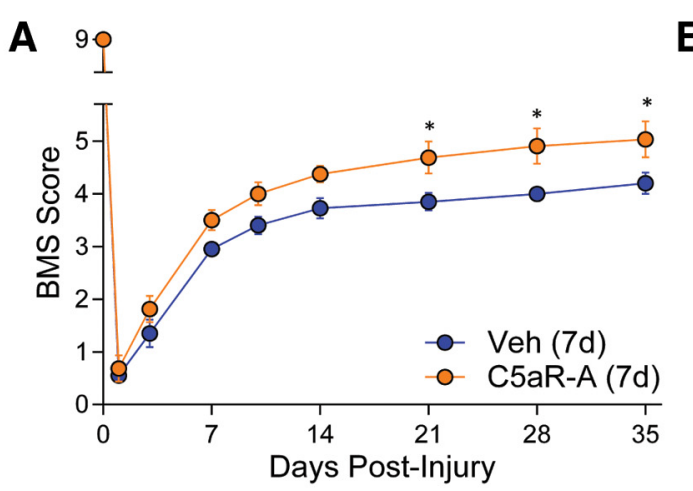

D

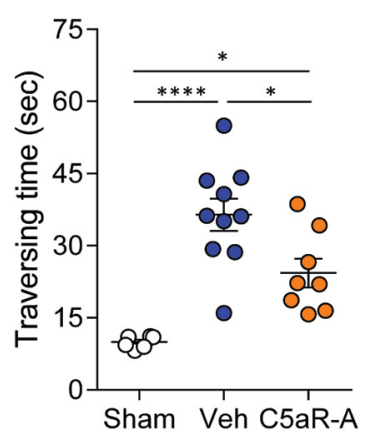

H

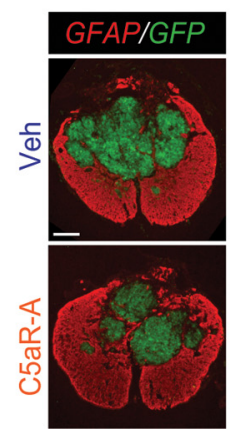

E

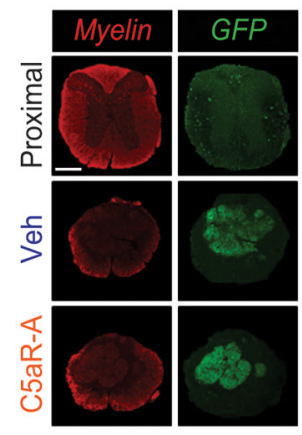

I

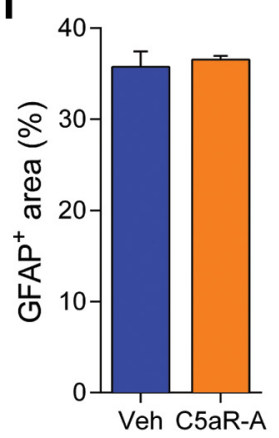

B

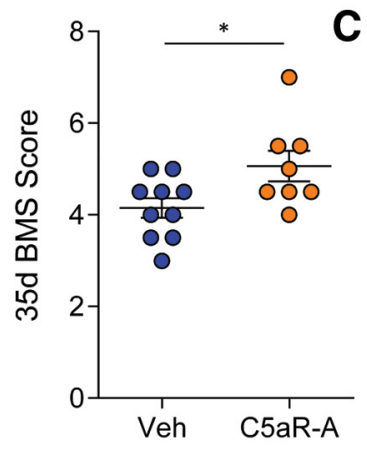

F
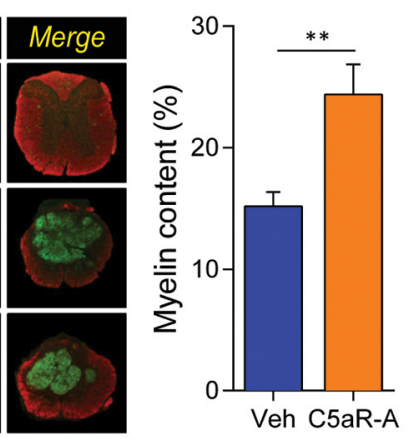

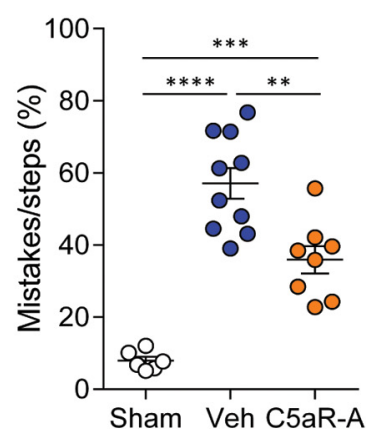

G

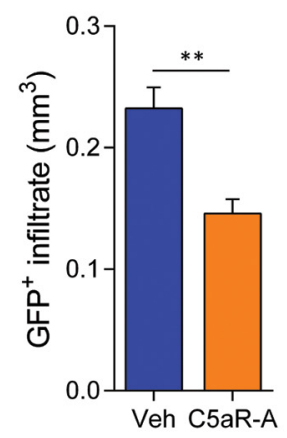

J

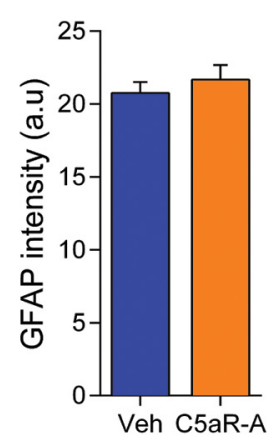

K

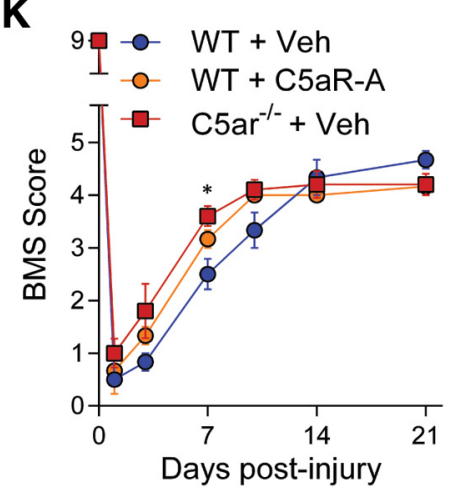

Figure 3. Acute, but not sustained, antagonism of (C5aR improves SCl outcomes in Macgreen mice. A, BMS locomotor scores of mice treated with a $C 5$ aR antagonist (C5aR-A) for $7 \mathrm{~d}$ after SCl have significantly higher BMS scores than vehicle (Veh)-treated mice at 21, 28, and $35 \mathrm{~d}$ after injury. ${ }^{*} p<0.05$ (two-way ANOVA with Bonferroni post hoc tests, $n=8-10$ ). $\boldsymbol{B}, A$ scatter plot depicting the BMS scores of individual mice at $35 \mathrm{~d}$ after SCI. ${ }^{*} p=0.029$ (Student's two-tailed $t$ test, $n=8-10$ ). C, D, Data from the ledged tapered beam walk task also indicated that C5aR blockade during the acute period improved long-term recovery, with C5aR-A-treated mice making significantly fewer stepping mistakes ( $($ ) and also traversing the beam faster (D) than vehicle-treated SCl controls. ${ }^{*} p<0.05 ;{ }^{* *} p<0.01 ;{ }^{* * *} p<0.001 ;{ }^{* * *} p<0.0001$ (one-way ANOVA with Newman-Keuls post hoc tests, $n=6-10$ ). $\boldsymbol{E}, \boldsymbol{F}$, (Sub)acute C5aR-A treatment resulted in significantly more myelin being present at the lesion epicenter at $35 \mathrm{~d}$ after SCl compared with vehicle-treated mice. ${ }^{* *} p=0.0088$ (Student's $t$ test, $n=5$ per group). Scale bar: $\boldsymbol{E}$ (top left), $200 \mu \mathrm{m}$. $\boldsymbol{E}, \mathbf{G}$, The GFP ${ }^{+}$infiltrate in the lesion core of Macgreen mice was also significantly reduced following the (5aR-A treatment regimen. ${ }^{* *} p=0.0061$ (Student's two-sided $t$ test, $n=5$ per group). $H-J$, GFAP immunoreactivity at $35 \mathrm{~d}$ after $\mathrm{SCI}$ was not significantly different between treatment groups based on analysis of both proportional area $(\boldsymbol{I})$ and staining intensity $(\boldsymbol{J})$ ). Scale bar: $\boldsymbol{H}$ (top left), $200 \mu \mathrm{m}$. $\boldsymbol{K}$, Improved recovery from SCI was not sustained with continued (5aR-A administration. ${ }^{*} p<0.05,\left(5 \mathrm{ar}^{-1-}+\right.$ vehicle versus WT + vehicle (two-way ANOVA with Bonferroni post hoc tests, $n=4$ or 5 ).

amount of myelin at the lesion epicenter (Fig. 5D), Ly6b.2 ${ }^{+}$cellular infiltrate (Fig. 5E), CD11b ${ }^{+}$immunoreactivity (Fig. $5 F$ ), and $\mathrm{CD} 3^{+}$T-cell numbers (Fig. $5 G$ ). Together, these data suggest that both the early injurious role of C5aR and its more delayed neuroprotective/reparative actions in the postacute phase are mostly mediated through resident CNS cells and not circulating immune cells.

\section{$\mathrm{C} 5 \mathrm{aR}$ regulates astrocyte proliferation and glial scar formation in vivo}

Our next aim was to understand why genetic ablation or continued pharmacological blockade of C5aR adversely affected recovery in the more chronic period of SCI. Based on one of our initial observations that $\mathrm{C} \mathrm{ar}^{-1-}$ mice had reduced myelin content at $35 \mathrm{~d}$ after SCI (Fig. $2 F, G$ ), we first explored whether C5aR signaling may be required for oligodendrocyte precursor cell proliferation (and/or survival) in response to SCI. To test this, BrdU was administered daily for the first $7 \mathrm{~d}$ after SCI to WT mice that were treated for $21 \mathrm{~d}$ with either C5aR-A or vehicle, as well as to a cohort of vehicle-treated $\mathrm{C}_{5} \mathrm{rr}^{-1-}$ mice. The experimental endpoint of $21 \mathrm{~d}$ after SCI was chosen based on a previous study showing that deficiency in C5 (i.e., the parental protein from which C5a is generated) leads to impaired remyelination in experimental autoimmune encephalitis at this stage (Weerth et al., 2003).

Quantification of the total $\left(\mathrm{CC}^{+}\right)$and newly generated $\left(\mathrm{CCl}^{+} \mathrm{BrdU}^{+}\right)$oligodendrocytes in spared white matter at and 
A

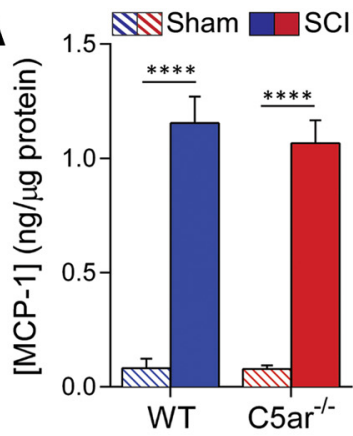

D

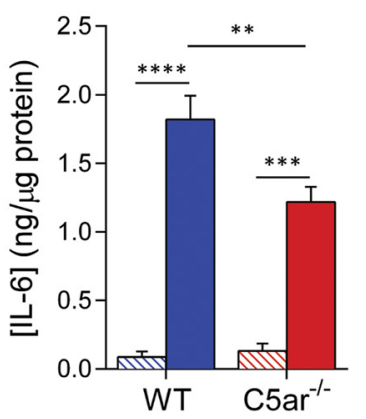

G
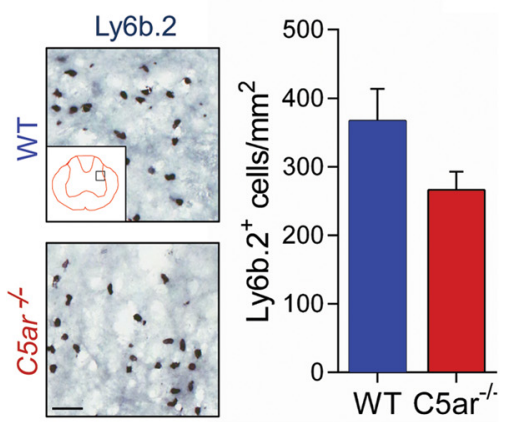

H

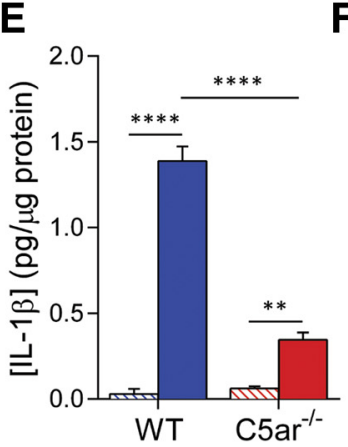

F

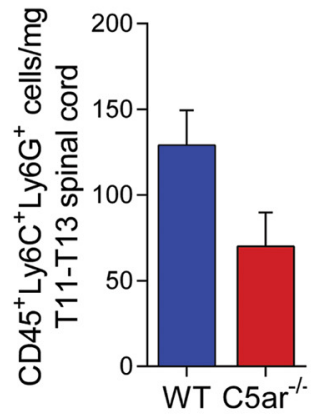

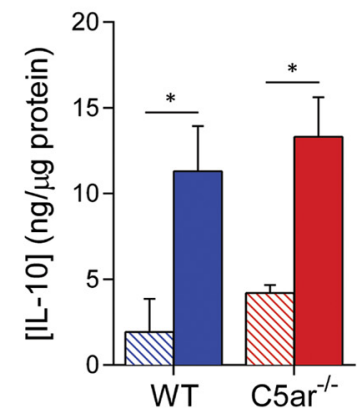

I

C

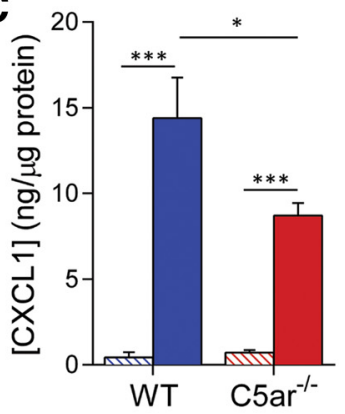

WT $\mathrm{C}^{2} \mathrm{ar}^{-1-}$

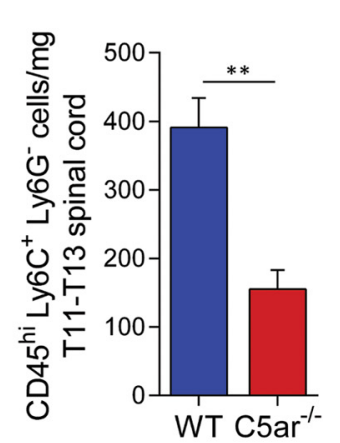

Figure 4. Inflammation in the (sub)acute period of SCl is reduced with C5aR elimination. $\boldsymbol{A}-\boldsymbol{F}$, Levels of MCP-1 (A)), TNF (B), CXCL1 (C), IL-6 (D), IL-1 $\beta(\boldsymbol{E})$, and IL-10 $(\boldsymbol{F})$ were all significantly increased at $12 \mathrm{~h}$ after SCI compared with sham-operated controls, regardless of genotype. C5aR deficiency did, however, result in significant reductions in CXCL1, IL-6, and IL- $1 \beta$ in the injured spinal cord compared with WT mice. ${ }^{*} p<0.05 ;{ }^{* *} p<0.01 ;{ }^{* * *} p<0.001 ;{ }^{* * * *} p<0.0001$ (two-way ANOVA with Newman-Keuls post hoc tests, $n=4$ or 5). $\mathbf{G}, \boldsymbol{H}$, No significant differences in the Ly6b. $2^{+}$inflammatory cell infiltrate were observed between WT and $\left(5 a^{-1-}\right.$ mice at $1 \mathrm{~d}(\boldsymbol{G})$ and $7 \mathrm{~d}(\boldsymbol{H})$ after SCI. Scale bar: $\boldsymbol{G}$ (bottom image), $40 \mu \mathrm{m}$. $\boldsymbol{I}$, A significant reduction in the number of inflammatory monocytes/macrophages was observed in injured ${\mathrm{C} 5 \mathrm{ar}^{-1-}}^{-}$spinal cord at $7 \mathrm{~d}$ after $\mathrm{SCl} .{ }^{* *} p<0.01$ (Student's two-sided $t$ test). $n=5$ per group.

around the lesion epicenter at $21 \mathrm{~d}$ after SCI revealed no significant differences between any of the experimental groups $(p=$ 0.93). Specifically, a total of $27 \pm 7$ newborn oligodendrocytes were observed at the lesion epicenter in vehicle-treated WT mice compared with $29 \pm 4$ cells in C5aR-A-treated WT mice and $26 \pm$ 3 cells for $\mathrm{C} \mathrm{ar}^{-1-}$ mice. Total CC1 ${ }^{+}$cell numbers were also not different between the experimental groups $(p=0.94)$, with $356 \pm 46$ cells counted in vehicle-treated controls compared with $351 \pm 65$ cells for C5aR-A-treated WT mice and $328 \pm 57$ cells for $\mathrm{C}_{5 \mathrm{ar}}{ }^{-1-}$ mice. We also observed no differences in the number of apoptotic (Cleaved Caspase- $3^{+} \mathrm{CC}^{+}$) oligodendrocytes between the experimental groups at the lesion epicenter $(p=0.87)$. Specifically, a total of $10 \pm 3$ cells was counted here in vehicle-treated WT mice, compared with $9 \pm$ 2 cells in C5aR-A-treated WT mice and $11 \pm 2$ cells in $\mathrm{C} 5 \mathrm{ar}^{-1-}$ mice. Similar results for each of the above quantitative analyses were obtained between experimental groups for

distances up to at least $600 \mu \mathrm{m}$ in both rostral and caudal directions (data not shown).

Given that neither genetic nor pharmacological disabling of the C5a-C $5 \mathrm{aR}$ axis appeared to affect oligodendrocyte generation and survival, we next investigated whether astrocyte proliferation was impaired under C5aR-deficient conditions. Quantification of $\mathrm{BrdU}^{+} \mathrm{GFAP}^{+}$cells revealed that there was a significant reduction in the number of newly generated astrocytes present at the lesion margins in the absence of C5aR signaling at $21 \mathrm{~d}$ after SCI (Fig. $6 A ; p<$ $0.05)$. These findings are in agreement with the observation that $\mathrm{C}_{5 \mathrm{ar}}^{-1-}$ mice had less GFAP ${ }^{+}$immunoreactivity at $35 \mathrm{~d}$ after SCI (Fig. $2 F, H, I$ ), and indicate that impaired formation of the glial scar may have led to a greater spread of secondary injury due to a failure to effectively seal off the lesion site (Faulkner et al., 2004; Herrmann et al., 2008). Consistent with that, the total number of $\mathrm{BrdU}^{+} \mathrm{GFAP}^{+}$astrocytes across the analyzed segment of the lesioned spinal cord was strongly and negatively correlated with the lesion volume (Fig. $6 B ; p<0.0001$ ).

\section{C5a promotes astrocyte proliferation and STAT3 phosphorylation in vitro}

Given the observation that interference with $\mathrm{C} 5 \mathrm{aR}$ signaling reduced astrocyte proliferation in vivo, we next directly tested the premise that C5a promotes the proliferation of these cells in vitro. Exposure of cultured astrocytes to C5a indeed elicited a dose-dependent proliferative response, with significantly more astrocytes being present in the cultures following stimulation with $\mathrm{C} 5 \mathrm{a}$ concentrations of 10, 50 100, and $200 \mathrm{~nm}$ compared with baseline (Fig. 6C). Having already established that cultured astrocytes express C5aR (Fig. 1G), we next examined whether the proliferative effect of $\mathrm{C} 5 \mathrm{a}$ was mediated via activation of this particular receptor. Exposure of $\mathrm{C} \mathrm{ar}^{-1-}$ astrocytes to $\mathrm{C} 5 \mathrm{a}$ failed to induce a proliferative response (Fig. 6D), thereby confirming that this effect requires the presence of C5aR.

Based on previous demonstrations that activation of the STAT3 pathway plays a critical role in astrocyte proliferation and the neuroprotective properties of the glial scar (Okada et al., 2006; Herrmann et al., 2008; Wanner et al., 2013), we next investigated whether STAT3 phosphorylation in astrocytes occurs downstream of C5aR following C5a stimulation. The amount of phosphorylated STAT3 (P-STAT3) was found to be markedly (2.5fold) increased in response to C5a stimulation (50 nM), an effect that could be blocked if the STAT3 inhibitor BP-1-102 was added just before C5a exposure (Fig. 6E). No increase in STAT3 phosphorylation was observed in $\mathrm{C}_{5} \mathrm{ar}^{-1-}$ astrocytes following exposure to $\mathrm{C} 5 \mathrm{a}$ (Fig. $6 \mathrm{~F}$ ). In the final experiment, we tested whether 
A

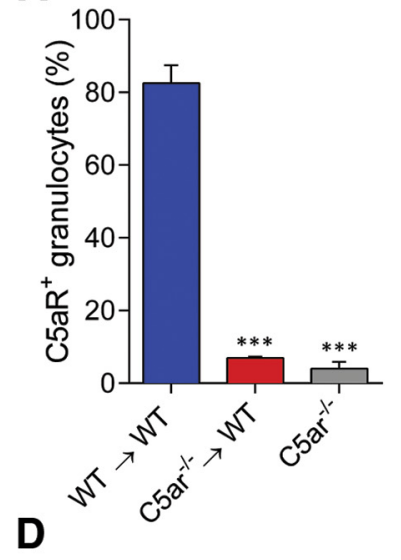

B

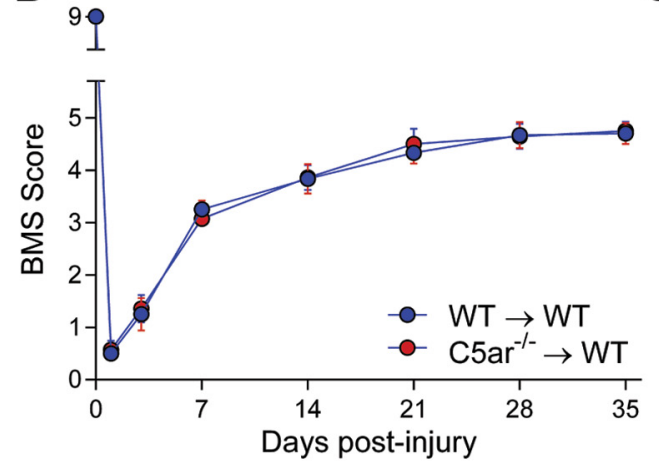

$\mathbf{E}$

$\mathbf{F}$
C

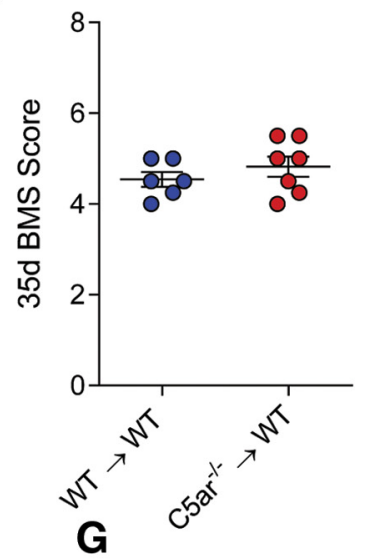

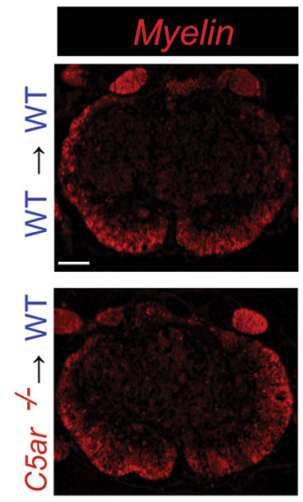
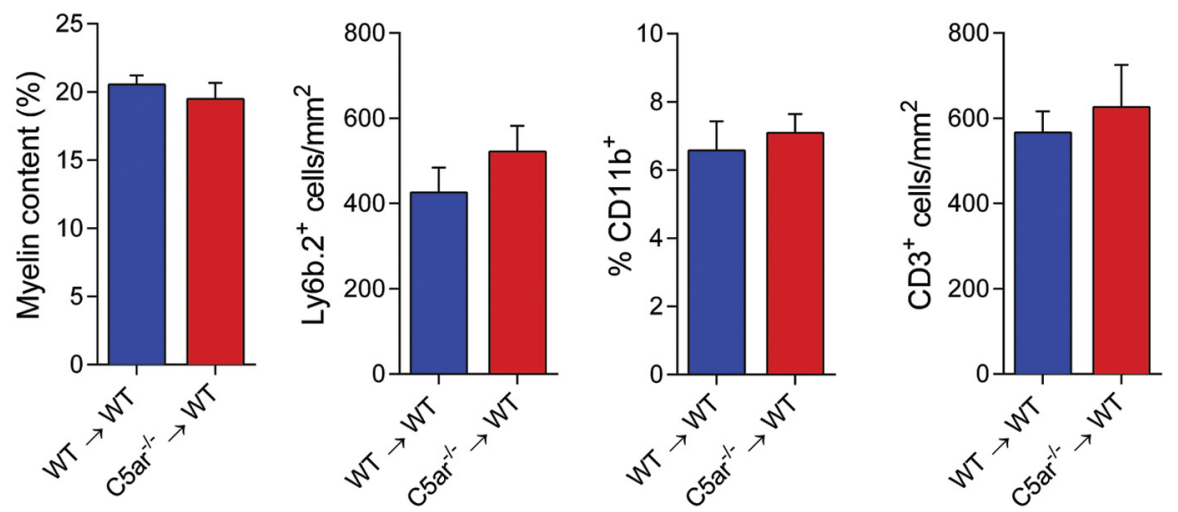

Figure 5. C5aR deficiency in the peripheral immune compartment does not alter the outcome from SCl. $A$, Flow cytometry data showing chimerization efficacy. [C5ar ${ }^{-\prime-} \rightarrow W T$ ] BM chimeras (i.e., WT mice that received a $\mathrm{C} \mathrm{ar}^{-1-}$ bone marrow transplant) only express background levels of $\mathrm{C} 5 \mathrm{aR}$ on circulating granulocytes, equivalent to the amount of nonspecific staining observed on $\mathrm{CSar}^{-1-}$ cells. ${ }^{* * *} p<0.001$ (one-way ANOVA with Newman-Keuls posthoc). $n=3-7 . B$, BMS locomotor scoring revealed no significant differences in functional recovery as a result of select C5aR deficiency in the peripheral immune compartment compared with [WT $\rightarrow$ WT] controls (two-way ANOVA with Bonferroni post hoc tests; $n=6$ or 7). C, Scatter plot showing main BMS scores for individual mice at $35 \mathrm{~d}$ after SCI. D, No difference was observed between the experimental groups in the amount of myelin within the ventrolateral white matter at $35 \mathrm{~d}$ after SCI (Student's two-sided $t$ test, $p>0.05 ; n=6$ or 7). Scale bar: $\boldsymbol{D}$ (top), $200 \mu \mathrm{m}$. $\boldsymbol{E}-\mathbf{G}$, Quantification of the inflammatory infiltrate also showed no differences between the experimental groups in the number of Ly6b. $2^{+}$ cells $(\boldsymbol{E})$, the proportional area of $\left(\mathrm{D} 11 \mathrm{~b}^{+}{ }^{+}\right.$immunoreactivity $(\boldsymbol{F})$, and the number of $\mathrm{CD} 3{ }^{+}$lymphocytes $(\boldsymbol{G})$ present at the lesion epicenter (Student's two-sided $t$ tests, $p>0.05 ; n=6$ or 7 ).

activation of the STAT3 pathway was driving astrocyte proliferation in response to C5a. Treatment with BP-1-102 indeed annulled the proliferative effect of C5a on astrocytes (Fig. 6G). Collectively, these findings indicate that $\mathrm{C} 5 \mathrm{a}$-induced phosphorylation of STAT3 occurs downstream of C5aR, which in turn drives astrocyte proliferation.

\section{Discussion}

Complement activation in CNS injury is predominantly considered deleterious to recovery. Specifically, complement proteins are thought to contribute to secondary injury through opsonization and membrane attack complex formation (for review, see Brennan et al., 2012). Other complement activation products appear to have more complex or even biphasic roles (Beck et al., 2010). We report that eliminating $\mathrm{C} 5 \mathrm{aR}$ signaling attenuates proinflammatory cytokine expression at the lesion site acutely after injury. This was followed by reduced macrophage recruitment and improved recovery of hindlimb function at $7 \mathrm{~d}$ after SCI. Importantly, and consistent with Beck et al. (2010), lack of C5aR signaling in the postacute period was detrimental to recovery. Experiments in BM chimeric mice suggested that these dual and opposing roles of C5aR are predominantly mediated via CNS cells and not infiltrating immune cells. Additional in vivo and in vitro studies demonstrated that $\mathrm{C} 5 \mathrm{aR}$ signaling regulates astrocyte proliferation, at least partly by STAT3 phosphorylation. We therefore postulate that whereas acute/subacute blockade of C5aR improves recovery, prolonged interference with C5aR signaling leads to impaired scar formation and reduced ability to confine pathology, as evidenced by poorer neurological recovery, larger lesion volumes, and more widespread presence of immune cells along the spinal axis.

\section{Time course of complement activation in SCI}

Previous studies clearly demonstrated the occurrence of complement system activation following SCI, with abnormal expression and/or deposition of C1q, factor B, C3, C4, C7, and membrane attack complex on neurons, glia, and infiltrating immune cells (Anderson et al., 2004; Qiao et al., 2006; Nguyen et al., 2008; Ankeny et al., 2009). The present data show that complement activation peaks locally at 12-24 h after SCI based on C5a levels. Extrinsic pathway activity likely plays a major role in C5a generation during this early phase due to microhemorrhaging (HuberLang et al., 2006). C5a levels remained significantly elevated up to $7 \mathrm{~d}$ after SCI but decreased thereafter to concentrations that were only slightly elevated from baseline. SCI also elicited a sharp rise in plasma C5a levels, which were significantly elevated over sham-operated controls up to $1 \mathrm{~d}$ after injury. Thus, robust increases in C5a levels occur in the blood and spinal cord during the first week of injury. 
A

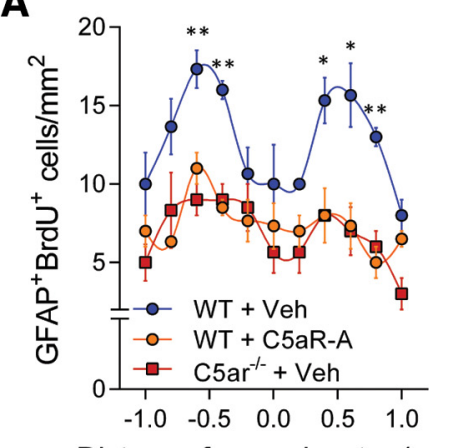

Distance from epicentre $(\mathrm{mm})$

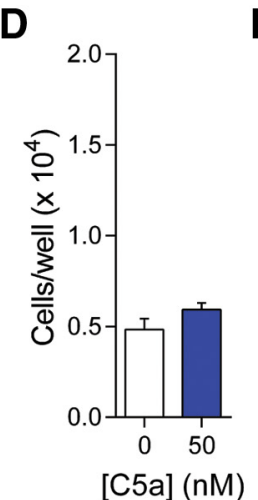

E

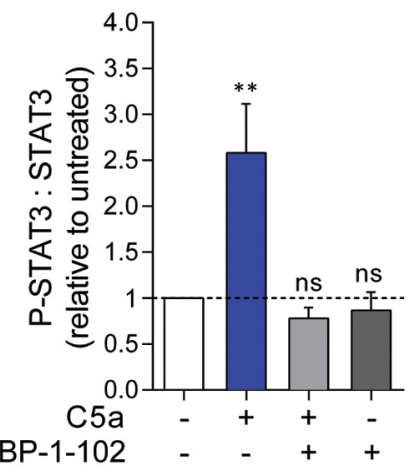

B

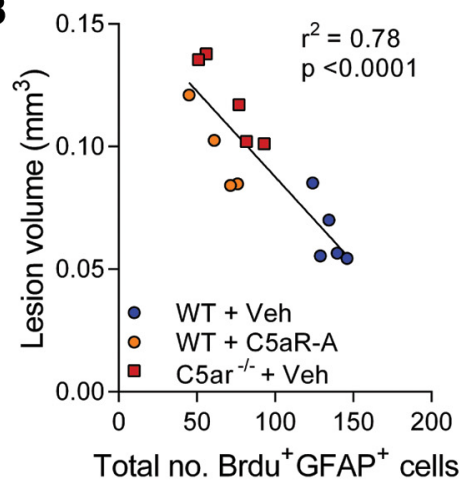

C

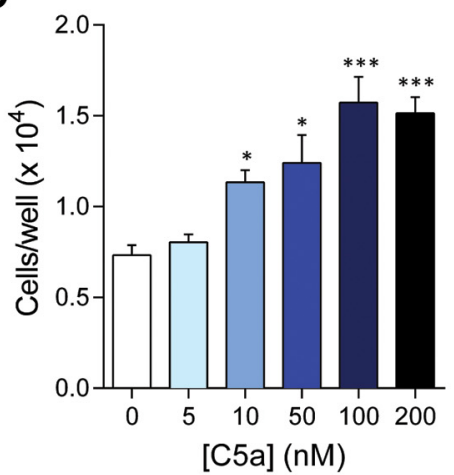

G
$\mathbf{F}$
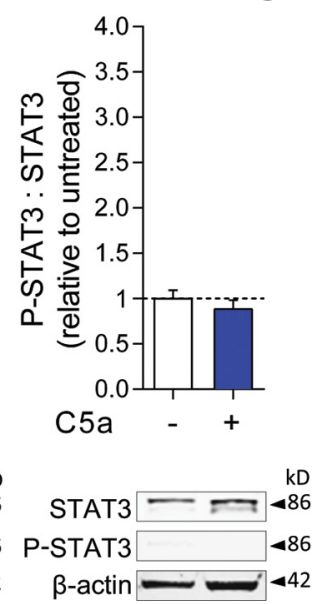

$\beta$-actin -42
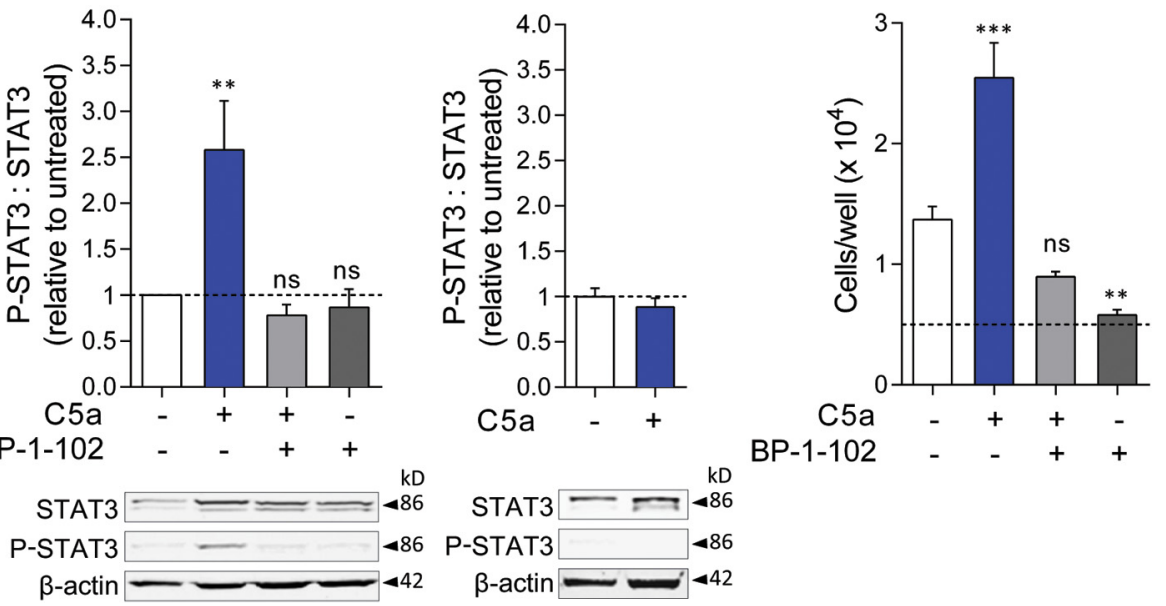

Figure 6. Signaling through the C5a-C5aR axis promotes astrocyte proliferation in vivo and in vitro. A, Quantification of $\mathrm{BrdU}^{+} \mathrm{GFAP}^{+}$astrocytes at the lesion site of WT SCI mice that were chronically administered (5aR-A (orange) or vehicle (Veh, blue) solution, and vehicle-treated $C_{5 a r^{-1}}$ - mice (red). Note the significantly reduced presence of newly generated astrocytes along the rostral and caudal margins of the lesion in the absence of C5aR signaling (two-way ANOVA with Newman-Keuls post hoc tests; $n=4$ or 5 per group). ${ }^{*} p<0.05 .{ }^{* *} p<0.01$. B, A significant, negative correlation was observed between the total number of $\mathrm{BrdU}^{+} \mathrm{GFAP}^{+}$cells and lesion volumes (Pearson's correlation, $p<0.0001$ ). C, (5a stimulates the proliferation of WT astrocytes in vitro in a dose-dependent manner at concentrations $>10 \mathrm{~nm}$ (one-way ANOVA with Newman-Keuls posthoc tests). ${ }^{*} p<0.05 .{ }^{* * *} p<0.001$. Graph is representative of three experimental repeats. $\boldsymbol{D}, \mathrm{CSar}^{-1-}$ astrocytes did not proliferate in response to high-dose C5a (50 nм; Student's two-sided ttest, $\left.p>0.05\right)$. E, Exposure of cultured astrocytes to C5a ( $\left.50 \mathrm{~nm}\right)$ resulted in a significant increase in the ratio of P-STAT3 to STAT3. Addition of the STAT3 Inhibitor BP-1-102 (10 $\mu$ M) just before C5a stimulation blocked this increase in STAT3 phosphorylation (one-way ANOVA with Newman-Keuls posthoc tests). ${ }^{* *} p<0.01$. F, Stimulation of (5ar ${ }^{-1-}$ astrocytes with $50 \mathrm{~nm}$ of (5a did not lead to a significant change in STAT3 phosphorylation (Student's two-sided $t$ test, $\left.p>0.05\right)$. G, Addition of BP-1-102 (5 $\mu \mathrm{M})$ blocked (5a-induced astrocyte proliferation in vitro (one-way ANOVA with Newman-Keuls post hoc tests). ${ }^{* *} p<0.01 .{ }^{* * *} p<0.001$. Dotted line indicates the initial number of cells plated. $\boldsymbol{D}-\boldsymbol{F}$, Data are mean \pm SEM, with $n=6$ biological replicates. ns, Not significant.

\section{C5aR inhibition in the acute/(sub)acute phase improves SCI recovery}

Characterization of the cellular infiltrate showed that recruitment of $\mathrm{CD} 45^{\text {hi }} \mathrm{Ly}_{6 \mathrm{C}}{ }^{+} \mathrm{Ly} 6 \mathrm{G}^{+}$granulocytes was not affected by C5aR deficiency at both 1 and $7 \mathrm{~d}$ after SCI. There was, however, a clear and significant reduction in the $\mathrm{CD} 45^{\mathrm{hi}} \mathrm{Ly} 6 \mathrm{C}^{+} \mathrm{Ly} 6 \mathrm{G}^{-}$infiltrate at $7 \mathrm{~d}$ after SCI in $\mathrm{C}_{5} \mathrm{ar}^{-1-}$ mice, suggesting reduced recruitment of inflammatory monocytes/macrophages (Blomster et al., 2013a). Overall, these findings are in agreement with previous observations that $\mathrm{C} 5 \mathrm{aR}$ antagonism in an equivalent rat model does not dramatically alter granulocyte presence but markedly reduces the number of ED $1^{+}$microglia/macrophages at $7 \mathrm{~d}$ after injury (Beck et al., 2010). Collectively, these data suggest that blocking $\mathrm{C} 5 \mathrm{aR}$ signaling attenuates activation and/or recruitment of select inflammatory cell populations, which coincides with improved recovery early on.

As C5aR is expressed in the CNS and peripheral immune compartment (Woodruff et al., 2010), BM chimera experiments were performed to determine the impact of C5aR deficiency exclusively on circulating leukocytes in relation to SCI outcomes. The outcome of these experiments suggested that the dual and oppos- ing roles of C5aR in SCI are predominantly mediated via CNSresident cells. Consistent with this, injury-induced expression of IL-6, IL-1 $\beta$, and CXCL1 within the spinal cord was significantly abrogated in absence of C5aR signaling at $12 \mathrm{~h}$ after SCI, a time point that coincides with high complement activation but precedes the first major wave of leukocyte infiltration (Kigerl et al., 2006; Beck et al., 2010).

IL- $1 \beta$ has previously been shown to promote injurious local inflammation, which correlates with impaired functional recovery (de Rivero Vaccari et al., 2012; Boato et al., 2013). Similarly, IL-6 polarizes macrophage toward a proinflammatory M1 phenotype, and treatment with anti-IL-6 antibody leads to a predominance of tissue-reparative M2 macrophages and improved recovery (Mukaino et al., 2010; Guerrero et al., 2012). Although we did not identify the precise cell population(s) responsible for proinflammatory cytokine production, astrocytes and microglia are likely candidates as they express C5aR (Fig. 1C) and rapidly respond to trauma (Pineau and Lacroix, 2007; Donnelly and Popovich, 2008; Pineau et al., 2010). We therefore postulate that the benefits of C5aR blockade during the acute/subacute phase of 
Day 0-7:

C5a is pro-inflammatory, C5aR antagonism is beneficial
Day 7-35:

C5a contributes to repair, C5aR antagonism is detrimental

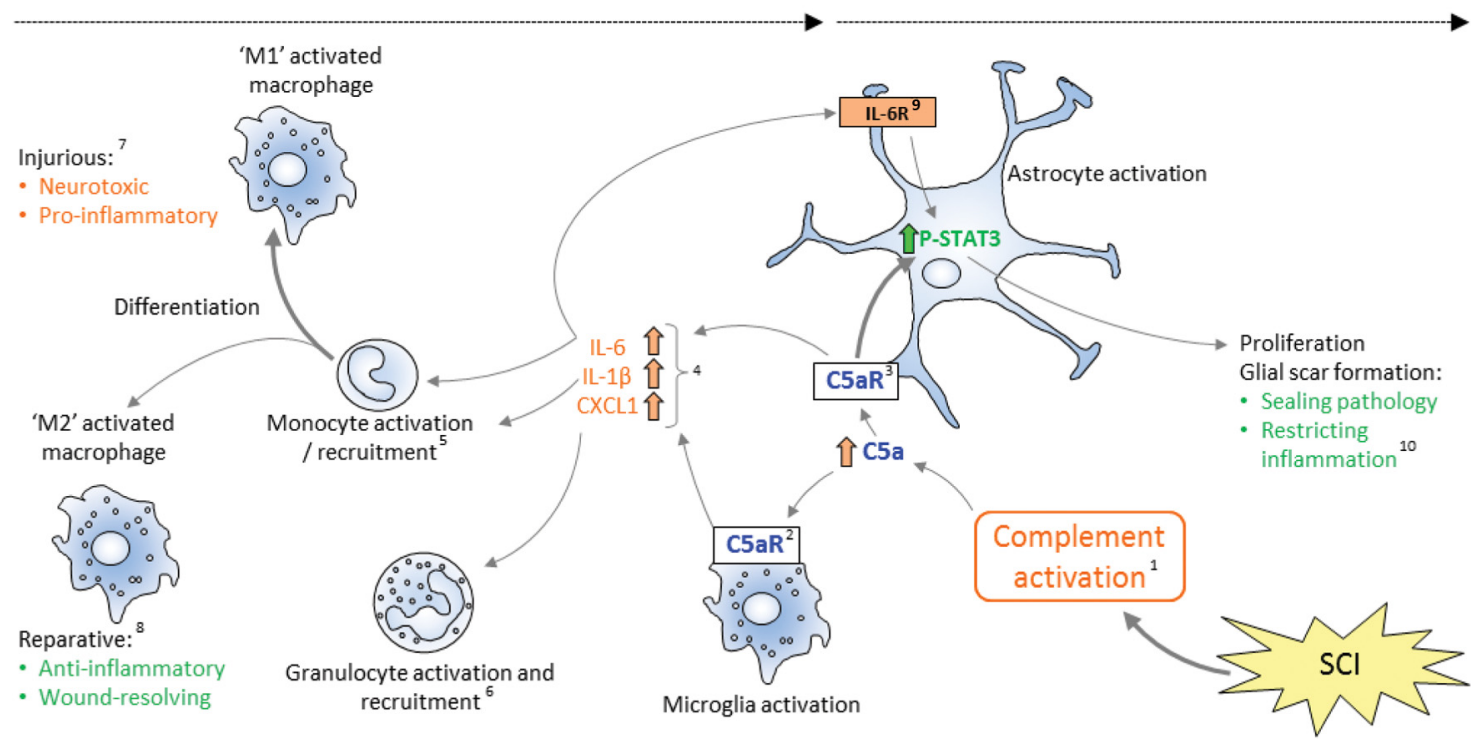

Figure 7. Diagram showing the proposed dual and time-dependent role of $\mathrm{C} 5 \mathrm{aR}$ in SCI. In the (sub)acute period ( $0-7 \mathrm{~d}$ after SCl), activated astrocytes and microglia proliferate and/or migrate to the site of injury. Activation of these cells occurs in part through increased C5a levels as a result of complement activation, which in turn augments their production and release of inflammatory cytokines at the lesion site. Release of CXCL1 is a key signal for neutrophil recruitment to the site of SCI. IL-1 $\beta$ and IL-6 aid in the recruitment of blood monocytes and macrophages, which promote secondary injury if adopting an M1 phenotype. In the postacute to chronic period of SCI (7 d after SCl onwards), C5aR signaling is critically required for STAT3-mediated astrocyte proliferation and glial scar formation, which seals the injury site and prevents the spread of secondary injury. Through its regulation of IL-6 levels, C5aR may also be involved IL-6R-dependent astrocyte proliferation. ${ }^{1}$ (Anderson etal., 2004, 2005; Nguyen et al., 2008); ${ }^{2}$ (Lacy et al., 1995; Griffin et al., 2007; Ager etal., 2010); ${ }^{3}$ (Gasque et al., 1995; Lacy etal., 1995; Woodruffet al., 2008); ${ }^{4}$ (Acarin et al., 2000; Pineau and Lacroix, 2007; Pineau et al., 2010); ${ }^{5}$ (Klusman and Schwab, 1997; Romano et al., 1997; Dinarello, 2009); ${ }^{6}$ (Baggiolini and Clark-Lewis, 1992; Harada et al., 1994; Taub et al., 1996); ${ }^{7}$ (Gensel et al., 2009; Kigerl et al., 2009; Blomster et al., 2013a); ${ }^{8}$ (Gensel et al., 2009; Shechter et al., 2009, 2013); ${ }^{9}$ (Okada et al., 2006); and ${ }^{10}$ (Bush et al., 1999; Faulkner et al., 2004; 0kada et al., 2006; Herrmann et al., 2008; Wanner et al., 2013).

SCI are primarily mediated through reduced proinflammatory cytokine production and associated neuroprotection (Farkas et al., 1998; Humayun et al., 2009; Pavlovski et al., 2012), with reduced recruitment of inflammatory Ly6 $\mathrm{C}^{+}$monocytes/macrophages at $7 \mathrm{~d}$ after SCI as a direct reflection of attenuated secondary injury. Targeting the C5a-C5aR pathway during the first hours to days after $\mathrm{SCI}$ is thus a credible therapeutic avenue to promote SCI recovery (Fig. 7).

\section{C5aR activation regulates astrocyte proliferation and glial scarring}

Although our findings clearly demonstrate that C5aR activation is deleterious to recovery in the acute/subacute period of SCI, lack of C5aR signaling in the chronic phase ultimately led to exacerbated injury outcomes. Specifically, ${\mathrm{C} 5 a r^{-1-}}^{-}$mice exhibited lower BMS scores, larger lesion volumes, less white matter myelin, and reduced glial scarring at $35 \mathrm{~d}$ after injury. Improvements obtained through pharmacological blockade of $\mathrm{C} 5 \mathrm{aR}$ were also lost if treatment was extended beyond the acute phase. Although a recent study by Li et al. (2014) did not report such a dual role for C5aR, our findings are consistent with earlier observations by Beck et al. (2010) who independently showed that chronic C5aR-A treatment similarly impairs recovery in rats. Unfortunately, Li et al. (2014) did not report lesion volumes or axonal/ myelin sparing as an independent accompaniment to functional testing, making a direct comparison between our studies difficult; additional differences in the lesion model of choice (computercontrolled impact vs manual compression with forceps) and mouse strains used (C57BL/6J vs BALB/c) (Kigerl et al., 2006) are likely contributors to this disparity. Regardless, the mecha- nism(s) contributing to the reparative/neuroprotective role of $\mathrm{C} 5 \mathrm{aR}$ in contusive SCI had remained unclear. Although previous studies suggested a possible role for $\mathrm{C} 5 \mathrm{a}$ in reparative remyelination following cuprizone treatment (Ingersoll et al., 2010), oligodendrocyte survival and/or proliferation of oligodendrocyte precursor cells appeared unaffected by disabling C5aR signaling in the context of SCI. As we observed a reduction in GFAP ${ }^{+}$ immunoreactivity in $\mathrm{C}^{2} \mathrm{ar}^{-1-}$ mice at the study endpoint, we investigated whether C5aR signaling had any effect on astrocyte proliferation. Our in vivo data revealed that both genetic ablation and pharmacological blockade of $\mathrm{C} 5 \mathrm{aR}$ inhibit astrocyte proliferation. This finding was supported by additional in vitro data showing that activation of $\mathrm{C} 5 \mathrm{aR}$ by $\mathrm{C} 5 \mathrm{a}$ induces astrocyte proliferation in a dose-dependent manner.

With previous research indicating a key role for STAT3 in protective glial scar formation (Okada et al., 2006; Herrmann et al., 2008; Wanner et al., 2013), we evaluated whether C5aR signaling in astrocytes promotes STAT3 pathway activation. Exposure of cultured astrocytes to C5a indeed leads to STAT3 phosphorylation via C5aR, an event that is critical for initiating downstream transcriptional events and cell proliferation. Intriguingly, Okada et al. (2004) demonstrated that IL-6 also promotes astrocyte proliferation via STAT3, which could be inhibited with anti-IL-6R antibody treatment (Okada et al., 2004). As we observed reduced IL-6 levels in $\mathrm{C}^{\mathrm{a}} \mathrm{rr}^{-1-}$ mice, it is likely that this may have further impaired astrocyte proliferation in vivo. Activation of the $\mathrm{C} 5 \mathrm{a}-\mathrm{C} 5 \mathrm{aR}$ axis may thus stimulate astrocyte proliferation directly as well as indirectly via IL-6 release from astrocytes and/or microglia. 
Importantly, pleiotropic roles for astrocytes and the glial scar have been ascribed (i.e., inhibitory from a regeneration perspective but neuroprotective with regards to secondary injury) (Bush et al., 1999; Faulkner et al., 2004; Silver and Miller, 2004; Rolls et al., 2009; Pineau et al., 2010; Cregg et al., 2014; Pekny et al., 2014). On the latter, demarcation of the lesion is achieved partly through astrocyte hyperplasia, which increases cell density up to fourfold in spinal white matter (Ertürk et al., 2012). By separating the injury core from neighboring intact neural tissue, astrocytes limit the spread of immune cells along the spinal axis, as previously reported (Okada et al., 2006), and observed here for the Ly $6 \mathrm{~b} .2^{+}$and $\mathrm{CD}^{+}{ }^{+}$infiltrate. We therefore postulate that the reparative/neuroprotective functions attributed to $\mathrm{C} 5 \mathrm{aR}$ signaling in the postacute phase of SCI (Beck et al., 2010) include its role in glial scar formation. Whether exogenous stimulation of astrocyte proliferation via $\mathrm{C} 5 \mathrm{aR}$ agonism during the postacute phase could indeed benefit recovery remains an outstanding question. It is also worth mentioning that our findings do not necessarily exclude a role for the alternate $\mathrm{C} 5$ a receptor, C5L2, in SCI. They do, however, show that, at least for the induction of proinflammatory cytokine expression and astrocyte proliferation, expression of $\mathrm{C} 5 \mathrm{aR}$ is required.

In conclusion, the present findings confirm $\mathrm{C} 5 \mathrm{aR}$ as a promising therapeutic target in SCI, demonstrating that timely pharmacological inhibition of this receptor can reduce immune-mediated secondary damage and improve recovery. The identified key role for C5aR signaling in astrocyte proliferation and glial scarring during the chronic phase of SCI also highlights the importance, however, of fully understanding the dual and time-dependent functions that inflammatory mediators like C5a may have, such that adverse outcomes can be prevented by restricting treatments to critical windows.

\section{References}

Acarin L, González B, Castellano B (2000) Neuronal, astroglial and microglial cytokine expression after an excitotoxic lesion in the immature rat brain. Eur J Neurosci 12:3505-3520. CrossRef Medline

Ager RR, Fonseca MI, Chu SH, Sanderson SD, Taylor SM, Woodruff TM, Tenner AJ (2010) Microglial C5aR (CD88) expression correlates with amyloid-beta deposition in murine models of Alzheimer's disease. J Neurochem 113:389-401. CrossRef Medline

Anderson AJ, Robert S, Huang W, Young W, Cotman CW (2004) Activation of complement pathways after contusion-induced spinal cord injury. J Neurotrauma 21:1831-1846. CrossRef Medline

Anderson AJ, Najbauer J, Huang W, Young W, Robert S (2005) Upregulation of complement inhibitors in association with vulnerable cells following contusion-induced spinal cord injury. J Neurotrauma 22:382-397. CrossRef Medline

Ankeny DP, Guan Z, Popovich PG (2009) B cells produce pathogenic antibodies and impair recovery after spinal cord injury in mice. J Clin Invest 119:2990-2999. CrossRef Medline

Baggiolini M, Clark-Lewis I (1992) Interleukin-8, a chemotactic and inflammatory cytokine. FEBS Lett 307:97-101. CrossRef Medline

Basso DM, Fisher LC, Anderson AJ, Jakeman LB, McTigue DM, Popovich PG (2006) Basso Mouse Scale for locomotion detects differences in recovery after spinal cord injury in five common mouse strains. J Neurotrauma 23:635-659. CrossRef Medline

Beck KD, Nguyen HX, Galvan MD, Salazar DL, Woodruff TM, Anderson AJ (2010) Quantitative analysis of cellular inflammation after traumatic spinal cord injury: evidence for a multiphasic inflammatory response in the acute to chronic environment. Brain 133:433-447. CrossRef Medline

Bénard M, Gonzalez BJ, Schouft MT, Falluel-Morel A, Vaudry D, Chan P, Vaudry H, Fontaine M (2004) Characterization of C3a and C5a receptors in rat cerebellar granule neurons during maturation: neuroprotective effect of C5a against apoptotic cell death. J Biol Chem 279:43487-43496. CrossRef Medline

Blomster LV, Brennan FH, Lao HW, Harle DW, Harvey AR, Ruitenberg MJ (2013a) Mobilisation of the splenic monocyte reservoir and peripheral CXCR1 deficiency adversely affects recovery from spinal cord injury. Exp Neurol 247:226-240. CrossRef Medline

Blomster LV, Cowin GJ, Kurniawan ND, Ruitenberg MJ (2013b) Detection of endogenous iron deposits in the injured mouse spinal cord through high-resolution ex vivo and in vivo MRI. NMR Biomed 26:141-150. CrossRef Medline

Boato F, Rosenberger K, Nelissen S, Geboes L, Peters EM, Nitsch R, Hendrix S (2013) Absence of IL-1beta positively affects neurological outcome, lesion development and axonal plasticity after spinal cord injury. J Neuroinflammation 10:6. CrossRef Medline

Brennan FH, Anderson AJ, Taylor SM, Woodruff TM, Ruitenberg MJ (2012) Complement activation in the injured central nervous system: another dual-edged sword? J Neuroinflammation 9:137. CrossRef Medline

Bush TG, Puvanachandra N, Horner CH, Polito A, Ostenfeld T, Svendsen CN, Mucke L, Johnson MH, Sofroniew MV (1999) Leukocyte infiltration, neuronal degeneration, and neurite outgrowth after ablation of scarforming, reactive astrocytes in adult transgenic mice. Neuron 23:297-308. CrossRef Medline

Chenoweth DE, Hugli TE (1978) Demonstration of specific C5a receptor on intact human polymorphonuclear leukocytes. Proc Natl Acad Sci U S A 75:3943-3947. CrossRef Medline

Chenoweth DE, Goodman MG, Weigle WO (1982) Demonstration of a specific receptor for human C5a anaphylatoxin on murine macrophages. J Exp Med 156:68-78. CrossRef Medline

Chinnery HR, Ruitenberg MJ, McMenamin PG (2010) Novel characterization of monocyte-derived cell populations in the meninges and choroid plexus and their rates of replenishment in bone marrow chimeric mice. J Neuropathol Exp Neurol 69:896-909. CrossRef Medline

Cregg JM, DePaul MA, Filous AR, Lang BT, Tran A, Silver J (2014) Functional regeneration beyond the glial scar. Exp Neurol 253:197-207. CrossRef Medline

de Rivero Vaccari JP, Bastien D, Yurcisin G, Pineau I, Dietrich WD, De Koninck Y, Keane RW, Lacroix S (2012) P2X4 receptors influence inflammasome activation after spinal cord injury. J Neurosci 32:30583066. CrossRef Medline

Dinarello CA (2009) Immunological and inflammatory functions of the interleukin-1 family. Annu Rev Immunol 27:519-550. CrossRef Medline

Donnelly DJ, Popovich PG (2008) Inflammation and its role in neuroprotection, axonal regeneration and functional recovery after spinal cord injury. Exp Neurol 209:378-388. CrossRef Medline

Ertürk A, Mauch CP, Hellal F, Förstner F, Keck T, Becker K, Jährling N, Steffens H, Richter M, Hübener M, Kramer E, Kirchhoff F, Dodt HU, Bradke F (2012) Three-dimensional imaging of the unsectioned adult spinal cord to assess axon regeneration and glial responses after injury. Nat Med 18:166-171. CrossRef Medline

Farkas I, Baranyi L, Takahashi M, Fukuda A, Liposits Z, Yamamoto T, Okada H (1998) A neuronal C5a receptor and an associated apoptotic signal transduction pathway. J Physiol 507:679-687. CrossRef Medline

Farkas I, Baranyi L, Kaneko Y, Liposits Z, Yamamoto T, Okada H (1999) C5a receptor expression by TGW neuroblastoma cells. Neuroreport 10: 3021-3025. CrossRef Medline

Faulkner JR, Herrmann JE, Woo MJ, Tansey KE, Doan NB, Sofroniew MV (2004) Reactive astrocytes protect tissue and preserve function after spinal cord injury. J Neurosci 24:2143-2155. CrossRef Medline

Finch AM, Wong AK, Paczkowski NJ, Wadi SK, Craik DJ, Fairlie DP, Taylor SM (1999) Low-molecular-weight peptidic and cyclic antagonists of the receptor for the complement factor C5a. J Med Chem 42:1965-1974. CrossRef Medline

Garrett MC, Otten ML, Starke RM, Komotar RJ, Magotti P, Lambris JD, Rynkowski MA, Connolly ES (2009) Synergistic neuroprotective effects of C3a and C5a receptor blockade following intracerebral hemorrhage. Brain Res 1298:171-177. CrossRef Medline

Gasque P, Chan P, Fontaine M, Ischenko A, Lamacz M, Götze O, Morgan BP (1995) Identification and characterization of the complement C5a anaphylatoxin receptor on human astrocytes. J Immunol 155:4882-4889. Medline

Gensel JC, Nakamura S, Guan Z, van Rooijen N, Ankeny DP, Popovich PG (2009) Macrophages promote axon regeneration with concurrent neurotoxicity. J Neurosci 29:3956-3968. CrossRef Medline

Gordon R, Hogan CE, Neal ML, Anantharam V, Kanthasamy AG, Kanthasamy A (2011) A simple magnetic separation method for high-yield 
isolation of pure primary microglia. J Neurosci Methods 194:287-296. CrossRef Medline

Griffin RS, Costigan M, Brenner GJ, Ma CH, Scholz J, Moss A, Allchorne AJ, Stahl GL, WoolfCJ (2007) Complement induction in spinal cord microglia results in anaphylatoxin C5a-mediated pain hypersensitivity. J Neurosci 27:8699-8708. CrossRef Medline

Guerrero AR, Uchida K, Nakajima H, Watanabe S, Nakamura M, Johnson WE, Baba H (2012) Blockade of interleukin-6 signaling inhibits the classic pathway and promotes an alternative pathway of macrophage activation after spinal cord injury in mice. J Neuroinflammation 9:40. CrossRef Medline

Guo Q, Li S, Liang Y, Zhang Y, Zhang J, Wen C, Lin S, Wang H, Su B (2010) Effects of $\mathrm{C} 3$ deficiency on inflammation and regeneration following spinal cord injury in mice. Neurosci Lett 485:32-36. CrossRef Medline

Harada A, Sekido N, Akahoshi T, Wada T, Mukaida N, Matsushima K (1994) Essential involvement of interleukin-8 (IL-8) in acute inflammation. J Leukoc Biol 56:559-564. Medline

Harrison M, O'Brien A, Adams L, Cowin G, Ruitenberg MJ, Sengul G, Watson C (2013) Vertebral landmarks for the identification of spinal cord segments in the mouse. Neuroimage 68:22-29. CrossRef Medline

Herrmann JE, Imura T, Song B, Qi J, Ao Y, Nguyen TK, Korsak RA, Takeda K, Akira S, Sofroniew MV (2008) STAT3 is a critical regulator of astrogliosis and scar formation after spinal cord injury. J Neurosci 28:7231-7243. CrossRef Medline

Hollmann TJ, Mueller-Ortiz SL, Braun MC, Wetsel RA (2008) Disruption of the $\mathrm{C} 5 \mathrm{a}$ receptor gene increases resistance to acute $\mathrm{Gram}$-negative bacteremia and endotoxic shock: opposing roles of C3a and C5a. Mol Immunol 45:1907-1915. CrossRef Medline

Huber-Lang M, Sarma JV, Zetoune FS, Rittirsch D, Neff TA, McGuire SR, Lambris JD, Warner RL, Flierl MA, Hoesel LM, Gebhard F, Younger JG, Drouin SM, Wetsel RA, Ward PA (2006) Generation of C5a in the absence of C3: a new complement activation pathway. Nat Med 12:682-687. CrossRef Medline

Humayun S, Gohar M, Volkening K, Moisse K, Leystra-Lantz C, Mepham J, McLean J, Strong MJ (2009) The complement factor C5a receptor is upregulated in $\mathrm{NFL}^{-1-}$ mouse motor neurons. J Neuroimmunol 210:52-62. CrossRef Medline

Ingersoll SA, Martin CB, Barnum SR, Martin BK (2010) CNS-specific expression of $\mathrm{C} 3 \mathrm{a}$ and $\mathrm{C} 5 \mathrm{a}$ exacerbate demyelination severity in the cuprizone model. Mol Immunol 48:219-230. CrossRef Medline

Kigerl KA, McGaughy VM, Popovich PG (2006) Comparative analysis of lesion development and intraspinal inflammation in four strains of mice following spinal contusion injury. J Comp Neurol 494:578-594. CrossRef Medline

Kigerl KA, Gensel JC, Ankeny DP, Alexander JK, Donnelly DJ, Popovich PG (2009) Identification of two distinct macrophage subsets with divergent effects causing either neurotoxicity or regeneration in the injured mouse spinal cord. J Neurosci 29:13435-13444. CrossRef Medline

Kim GH, Mocco J, Hahn DK, Kellner CP, Komotar RJ, Ducruet AF, Mack WJ, Connolly ES Jr (2008) Protective effect of C5a receptor inhibition after murine reperfused stroke. Neurosurgery 63:122-125; discussion 125126. CrossRef Medline

Klusman I, Schwab ME (1997) Effects of pro-inflammatory cytokines in experimental spinal cord injury. Brain Res 762:173-184. CrossRef Medline

Lacy M, Jones J, Whittemore SR, Haviland DL, Wetsel RA, Barnum SR (1995) Expression of the receptors for the C5a anaphylatoxin, interleukin-8 and FMLP by human astrocytes and microglia. J Neuroimmunol 61:71-78. CrossRef Medline

Li L, Li J, Zhu Y, Fan G (2009) Ephedra sinica inhibits complement activation and improves the motor functions after spinal cord injury in rats. Brain Res Bull 78:261-266. CrossRef Medline

Li L, Xiong ZY, Qian ZM, Zhao TZ, Feng H, Hu S, Hu R, Ke Y, Lin J (2014) Complement $\mathrm{C} 5 \mathrm{a}$ is detrimental to histological and functional locomotor recovery after spinal cord injury in mice. Neurobiol Dis 66:74-82. CrossRef Medline

Lytle JM, Wrathall JR (2007) Glial cell loss, proliferation and replacement in the contused murine spinal cord. Eur J Neurosci 25:1711-1724. CrossRef Medline

Mack WJ, Ducruet AF, Hickman ZL, Garrett MC, Albert EJ, Kellner CP, Mocco J, Connolly ES Jr (2007) Early plasma complement C3a levels correlate with functional outcome after aneurysmal subarachnoid hem- orrhage. Neurosurgery 61:255-260; discussion 260-261. CrossRef Medline

Mocco J, Wilson DA, Komotar RJ, Sughrue ME, Coates K, Sacco RL, Elkind MS, Connolly ES Jr (2006) Alterations in plasma complement levels after human ischemic stroke. Neurosurgery 59:28-33. CrossRef Medline

Mukaino M, Nakamura M, Yamada O, Okada S, Morikawa S, RenaultMihara F, Iwanami A, Ikegami T, Ohsugi Y, Tsuji O, Katoh H, Matsuzaki Y, Toyama Y, Liu M, Okano H (2010) Anti-IL-6-receptor antibody promotes repair of spinal cord injury by inducing microglia-dominant inflammation. Exp Neurol 224:403-414. CrossRef Medline

Nataf S, Levison SW, Barnum SR (2001) Expression of the anaphylatoxin C5a receptor in the oligodendrocyte lineage. Brain Res 894:321-326. CrossRef Medline

Nguyen HX, Galvan MD, Anderson AJ (2008) Characterization of early and terminal complement proteins associated with polymorphonuclear leukocytes in vitro and in vivo after spinal cord injury. J Neuroinflammation 5:26. CrossRef Medline

O’Barr SA, Caguioa J, Gruol D, Perkins G, Ember JA, Hugli T, Cooper NR (2001) Neuronal expression of a functional receptor for the C5a complement activation fragment. J Immunol 166:4154-4162. CrossRef Medline

Okada S, Nakamura M, Mikami Y, Shimazaki T, Mihara M, Ohsugi Y, Iwamoto Y, Yoshizaki K, Kishimoto T, Toyama Y, Okano H (2004) Blockade of interleukin- 6 receptor suppresses reactive astrogliosis and ameliorates functional recovery in experimental spinal cord injury. J Neurosci Res 76:265-276. CrossRef Medline

Okada S, Nakamura M, Katoh H, Miyao T, Shimazaki T, Ishii K, Yamane J, Yoshimura A, Iwamoto Y, Toyama Y, Okano H (2006) Conditional ablation of Stat 3 or Socs 3 discloses a dual role for reactive astrocytes after spinal cord injury. Nat Med 12:829-834. CrossRef Medline

Pavlovski D, Thundyil J, Monk PN, Wetsel RA, Taylor SM, Woodruff TM (2012) Generation of complement component C5a by ischemic neurons promotes neuronal apoptosis. FASEB J 26:3680-3690. CrossRef Medline

Pekny M, Wilhelmsson U, Pekna M (2014) The dual role of astrocyte activation and reactive gliosis. Neurosci Lett 565:30-38. CrossRef Medline

Pineau I, Lacroix S (2007) Proinflammatory cytokine synthesis in the injured mouse spinal cord: multiphasic expression pattern and identification of the cell types involved. J Comp Neurol 500:267-285. CrossRef Medline

Pineau I, Sun L, Bastien D, Lacroix S (2010) Astrocytes initiate inflammation in the injured mouse spinal cord by promoting the entry of neutrophils and inflammatory monocytes in an IL-1 receptor/MyD88-dependent fashion. Brain Behav Immun 24:540-553. CrossRef Medline

Qiao F, Atkinson C, Song H, Pannu R, Singh I, Tomlinson S (2006) Complement plays an important role in spinal cord injury and represents a therapeutic target for improving recovery following trauma. Am J Pathol 169:1039-1047. CrossRef Medline

Qiao F, Atkinson C, Kindy MS, Shunmugavel A, Morgan BP, Song H, Tomlinson S (2010) The alternative and terminal pathways of complement mediate post-traumatic spinal cord inflammation and injury. Am J Pathol 177:3061-3070. CrossRef Medline

Rahpeymai Y, Hietala MA, Wilhelmsson U, Fotheringham A, Davies I, Nilsson AK, Zwirner J, Wetsel RA, Gerard C, Pekny M, Pekna M (2006) Complement: a novel factor in basal and ischemia-induced neurogenesis. EMBO J 25:1364-1374. CrossRef Medline

Reynolds DN, Smith SA, Zhang YP, Mengsheng Q, Lahiri DK, Morassutti DJ, Shields CB, Kotwal GJ (2004) Vaccinia virus complement control protein reduces inflammation and improves spinal cord integrity following spinal cord injury. Ann N Y Acad Sci 1035:165-178. CrossRef Medline

Rolls A, Shechter R, Schwartz M (2009) The bright side of the glial scar in CNS repair. Nat Rev Neurosci 10:235-241. CrossRef Medline

Romano M, Sironi M, Toniatti C, Polentarutti N, Fruscella P, Ghezzi P, Faggioni R, Luini W, van Hinsbergh V, Sozzani S, Bussolino F, Poli V, Ciliberto G, Mantovani A (1997) Role of IL-6 and its soluble receptor in induction of chemokines and leukocyte recruitment. Immunity 6:315325. CrossRef Medline

Rosas M, Thomas B, Stacey M, Gordon S, Taylor PR (2010) The myeloid $7 / 4$-antigen defines recently generated inflammatory macrophages and is synonymous with Ly-6B. J Leukoc Biol 88:169-180. CrossRef Medline

Sasmono RT, Oceandy D, Pollard JW, Tong W, Pavli P, Wainwright BJ, Ostrowski MC, Himes SR, Hume DA (2003) A macrophage colonystimulating factor receptor-green fluorescent protein transgene is ex- 
pressed throughout the mononuclear phagocyte system of the mouse. Blood 101:1155-1163. CrossRef Medline

Scheff SW, Rabchevsky AG, Fugaccia I, Main JA, Lumpp JE Jr (2003) Experimental modeling of spinal cord injury: characterization of a forcedefined injury device. J Neurotrauma 20:179-193. CrossRef Medline

Schmid AB, Coppieters MW, Ruitenberg MJ, McLachlan EM (2013) Local and remote immune-mediated inflammation after mild peripheral nerve compression in rats. J Neuropathol Exp Neurol 72:662-680. CrossRef Medline

Shechter R, London A, Varol C, Raposo C, Cusimano M, Yovel G, Rolls A, Mack M, Pluchino S, Martino G, Jung S, Schwartz M (2009) Infiltrating blood-derived macrophages are vital cells playing an anti-inflammatory role in recovery from spinal cord injury in mice. PLoS Med 6:e1000113. CrossRef Medline

Shechter R, Miller O, Yovel G, Rosenzweig N, London A, Ruckh J, Kim KW, Klein E, Kalchenko V, Bendel P, Lira SA, Jung S, Schwartz M (2013) Recruitment of beneficial M2 macrophages to injured spinal cord is orchestrated by remote brain choroid plexus. Immunity 38:555-569. CrossRef Medline

Silver J, Miller JH (2004) Regeneration beyond the glial scar. Nat Rev Neurosci 5:146-156. CrossRef Medline

Stahel PF, Kossmann T, Morganti-Kossmann MC, Hans VH, Barnum SR (1997) Experimental diffuse axonal injury induces enhanced neuronal C5a receptor mRNA expression in rats. Brain Res Mol Brain Res 50:205212. CrossRef Medline

Taub DD, Anver M, Oppenheim JJ, Longo DL, Murphy WJ (1996) T lymphocyte recruitment by interleukin-8 (IL-8): IL-8-induced degranulation of neutrophils releases potent chemoattractants for human T lymphocytes both in vitro and in vivo. J Clin Invest 97:1931-1941. CrossRef Medline

Tripathi R, McTigue DM (2007) Prominent oligodendrocyte genesis along the border of spinal contusion lesions. Glia 55:698-711. CrossRef Medline

Van Beek J, Bernaudin M, Petit E, Gasque P, Nouvelot A, MacKenzie ET,
Fontaine M (2000) Expression of receptors for complement anaphylatoxins C3a and C5a following permanent focal cerebral ischemia in the mouse. Exp Neurol 161:373-382. CrossRef Medline

Wanner IB, Anderson MA, Song B, Levine J, Fernandez A, Gray-Thompson Z, Ao Y, Sofroniew MV (2013) Glial scar borders are formed by newly proliferated, elongated astrocytes that interact to corral inflammatory and fibrotic cells via STAT3-dependent mechanisms after spinal cord injury. J Neurosci 33:12870-12886. CrossRef Medline

Ward PA, Newman LJ (1969) A neutrophil chemotactic factor from human C’5. J Immunol 102:93-99. Medline

Weerth SH, Rus H, Shin ML, Raine CS (2003) Complement C5 in experimental autoimmune encephalomyelitis (EAE) facilitates remyelination and prevents gliosis. Am J Pathol 163:1069-1080. CrossRef Medline

Woodruff TM, Crane JW, Proctor LM, Buller KM, Shek AB, de Vos K, Pollitt S, Williams HM, Shiels IA, Monk PN, Taylor SM (2006) Therapeutic activity of $\mathrm{C} 5$ a receptor antagonists in a rat model of neurodegeneration. FASEB J 20:1407-1417. CrossRef Medline

Woodruff TM, Costantini KJ, Crane JW, Atkin JD, Monk PN, Taylor SM, Noakes PG (2008) The complement factor C5a contributes to pathology in a rat model of amyotrophic lateral sclerosis. J Immunol 181:87278734. CrossRef Medline

Woodruff TM, Ager RR, Tenner AJ, Noakes PG, Taylor SM (2010) The role of the complement system and the activation fragment C5a in the central nervous system. Neuromolecular Med 12:179-192. CrossRef Medline

Xi G, Hua Y, Keep RF, Younger JG, Hoff JT (2001) Systemic complement depletion diminishes perihematomal brain edema in rats. Stroke 32:162167. CrossRef Medline

Zai LJ, Wrathall JR (2005) Cell proliferation and replacement following contusive spinal cord injury. Glia 50:247-257. CrossRef Medline

Zhang X, Yue P, Page BD, Li T, Zhao W, Namanja AT, Paladino D, Zhao J, Chen Y, Gunning PT, Turkson J (2012) Orally bioavailable smallmolecule inhibitor of transcription factor Stat3 regresses human breast and lung cancer xenografts. Proc Natl Acad Sci U S A 109:9623-9628. CrossRef Medline 